\title{
Article
}

\section{Openness, ICT and Entrepreneurship in Sub-Saharan Africa}

\author{
Asongu, Simplice and Nwachukwu, Jacinta Chikaodi \\ Available at http://clok.uclan.ac.uk/25159/ \\ Asongu, Simplice and Nwachukwu, Jacinta Chikaodi ORCID: 0000-0003-2987- \\ 9242 (2018) Openness, ICT and Entrepreneurship in Sub-Saharan Africa. \\ Information Technology and People, 31 (1). pp. 278-303. ISSN 0959-3845
}

It is advisable to refer to the publisher's version if you intend to cite from the work. http://dx.doi.org/10.1108/ITP-02-2017-0033

For more information about UCLan's research in this area go to

http://www.uclan.ac.uk/researchgroups/ and search for < name of research Group>.

For information about Research generally at UCLan please go to

http://www.uclan.ac.uk/research/

All outputs in CLoK are protected by Intellectual Property Rights law, including Copyright law. Copyright, IPR and Moral Rights for the works on this site are retained by the individual authors and/or other copyright owners. Terms and conditions for use of this material are defined in the policies page.

\section{CLoK}

Central Lancashire online Knowledge www.clok.uclan.ac.uk

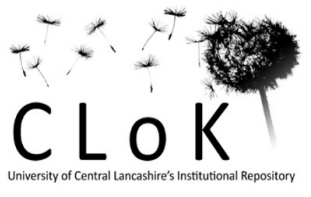




\section{MPRA \\ Munich Personal RePEc Archive}

\section{Openness, ICT and Entrepreneurship in Sub-Saharan Africa}

Simplice Asongu and Jacinta Nwachukwu

January 2017

Online at https://mpra.ub.uni-muenchen.de/83070/

MPRA Paper No. 83070, posted 2 December 2017 02:40 UTC 


\title{
$\underline{\text { A G D I Working Paper }}$
}

\author{
$\mathrm{WP} / 17 / 032$
}

\section{Openness, ICT and Entrepreneurship in Sub-Saharan Africa}

Forthcoming: Information Technology \& People

\section{Simplice A. Asongu}

African Governance and Development Institute,

P.O. Box 8413 Yaoundé, Cameroon.

E-mail: asongusimplice@yahoo.com / asongus@ afridev.org

\section{Jacinta C. Nwachukwu}

School of Economics, Finance and Accounting,

Faculty of Business and Law,

Coventry University Priory Street, Coventry, CV1 5FB, UK

Email: jacinta.nwachukwu@ coventry.ac.uk 
Research Department

\title{
Openness, ICT and Entrepreneurship in Sub-Saharan Africa
}

\section{Simplice A. Asongu \& Jacinta C. Nwachukwu}

January 2017

\begin{abstract}
This study has examined how information and communication technology (ICT) influences openness to improve the conditions of doing business in sub-Saharan Africa. The data is for the period 2000-2012. ICT is proxied with Internet and mobile phone penetration rates whereas openness is measured in terms of financial and trade globalisation. Ten indicators of doing business are used, namely: (i) cost of business start-up procedures; (ii) procedure to enforce a contract; (iii) start-up procedures to register a business; (iv) time required to build a warehouse; (v) time required to enforce a contract; (vi) time required to register a property; (vii) time required to start a business; (viii) time to export; (ix) time to prepare and pay taxes and (x) time to resolve an insolvency. The empirical evidence is based on Generalised Method of Moments with forward orthogonal deviations. While we find substantial evidence that ICT complements openness to improve conditions for entrepreneurship, the effects are contingent on the dynamics of openness, ICT and entrepreneurship. Theoretical and practical policy implications are discussed. The inquiry is based on two contemporary development concerns: the need for policy to leverage on the ICT penetration potential in the sub-region and the relevance of entrepreneurship in addressing associated issues of population growth such as unemployment.
\end{abstract}

JEL Classification: F40; O38; O40; O55; P37

Keywords: Openness; ICT; Entrepreneurship; Africa 


\section{Introduction}

Information and communication technology (ICT) serves to boost, inter alia: economic prosperity (Qureshi, 2013a; Levendis \& Lee, 2013); living standards (Chavula, 2013); externalities in welfare (Qureshi, 2013b, 2013c; Carmody, 2013); banking sector progress (Kamel, 2005); life for all (Ponelis \& Holmner, 2013a, 2013b; Kivuneki et al., 2011) and sustainable development (Byrne, 2011) in developing nations. Whereas ICT has been documented to benefit human and socio-economic developments, little is known about the connections between ICT, openness and doing business outcomes such as entrepreneurship ${ }^{1}$.

Examining the importance of ICT in openness for entrepreneurship in Sub-Saharan Africa (SSA) fundamentally builds on four trends in the literature, notably, the: evolving potential of ICT; relevance of openness in $21^{\text {st }}$ century economic prosperity ${ }^{2}$; role of entrepreneurship in addressing employment concerns in the post-2015 development agenda and gaps in the entrepreneurship literature (Qureshi et al., 2009; Brixiova et al., 2015; Asongu, 2015; Kuada, 2009, 2015; Asongu et al., 2016; Roztocki \& Weistroffer, 2016; Asongu \& Le Roux, 2017; Amavilah et al., 2017; Asongu \& Biekpe, 2017).

First, in relation to frontier economies in the Organisation for Economic Cooperation and Development (OECD) and Asia which are witnessing saturation levels in ICT penetration, there is a higher ICT growth potential in African peripheral markets (Penard et al., 2012; Asongu, 2017a). According to Penard et al. (2012), as of 2010, Internet and mobile phone penetration rates in the African continent were respectively $9.6 \%$ and $41 \%$. The SSA region has the lowest ICT penetration rate, while at the same time it has the highest ICT growth rate. Whereas ICT penetration is expected to engender development avenues, cautions have been raised in scholarly and policy circles not to conceive ICT as an economic development silver bullet (Mpogole et al., 2008, p.71).

Second, openness has been established to be unavoidable in $21^{\text {st }}$ century development. Accordingly, there is a well established consensus that integration into the worldwide economy is indispensable for development in the era of globalisation (Oluwatobi et al., 2015; Murphy \& Carmody, 2015; Tchamyou, 2016). The strand of studies underlying this consensus maintains that SSA is lagging in the drive towards the knowledge economy (KE) which is vital for contemporary economic prosperity (Anyanwu, 2012; Asongu, 2017b). In principle, whereas North America and Europe have being charting the course of development

\footnotetext{
${ }^{1}$ Entrepreneurship and 'doing business' are used interchangeably throughout the study.

${ }^{2}$ Openness may be used interchangeably with globalisation throughout the paper.
} 
in the international arena because of their comparatively higher KE drive, nations in Latin America and Asia are catching-up, partly because the Japanese KE course has determined the pattern for the newly industrialised economies of Asia. Consistent with recent African KE literature, compared to other regions of the world, the overall index of KE in Africa has been decreasing since the beginning of the third millennium (Anyanwu, 2012).

Third, the United Nations' population prospect has forecasted Africa's population could double by 2036 and represent approximately a fifth of the population in the world by 2050 (UN, 2009). A corresponding policy syndrome is the concern over the rising unemployment associated with the burgeoning demographic change (AERC, 2014). According to recent literature, the growing unemployment (especially among the youth) would be accommodated for the most part by entrepreneurship from the private sector (Brixiova et al., 2015). This is essentially because public investments would be less linked to such population growth and rising unemployment in the future (Asongu, 2013a). Whereas ICT can be leveraged to enhance entrepreneurship in order to address such unemployment challenges, as far as we are aware, the contemporary entrepreneurship literature has failed to connect with the ICT, openness and the doing of business. There is a growing body of literature on the employment of social media to promote entrepreneurship (Jones et al., 2015; McCann \& Barlow, 2015; Wang, 2016) and knowledge sharing in entrepreneurial success (Allen et al., 2016).

Fourth, the available entrepreneurship literature for the most part has focused on, among others, the: legal challenges to doing business (Taplin \& Synman, 2004); cost of doing business (Eifert et al., 2008); drivers of entrepreneurship in East Africa (Khavul et al., 2009); intensity by which trade affects business cycle synchronization (Tapsoba, 2010); effect of externalities in labour regulations on the cost of doing business (Paul et al., 2010); connection between financial literacy and youth entrepreneurship (Oseifuah, 2010); long-run povertyreducing effect of entrepreneurship (Mensah \& Benedict, 2010); intensions behind female entrepreneurs (Singh et al., 2011); motivation behind undergraduate students' ambition to become entrepreneurs (Gerba, 2012; Ita et al., 2014) and role of the knowledge economy in doing business (Tchamyou, 2016).

This study merges concerns from the four narratives above by assessing the role of ICT in openness for entrepreneurship in SSA. The corresponding research question this inquiry intends to address is: how does ICT complement openness to affect entrepreneurship in SSA? This positioning aims to extend recent theoretical and empirical literature on the 
benefits of information technology, notably in: improving conditions for human emancipation (Kautz, 2011; Venable et al., 2011; Hossain \& Quaddus, 2011; Johri \& Nair, 2011; Watts \& Wyner, 2011; Gripenberg, 2011) and changing society with opportunities for human development (Tatnall, 2015; Kreps \& Kimppa, 2015; Lennerfors et al., 2015; Aricat, 2015; Lahtiranta et al., 2015; Patrignani \& Whitehouse, 2015).

The rest of the study is structured as follows. Section 2 covers the theoretical underpinnings and related literature on which the study is built. Section 3 discusses the data and explains why the Generalised Method of Moments is employed as the estimation technique in the work. The empirical results are presented and discussed in Section 4 with emphasis on practical and theoretical policy implications. The conclusion in Section 5 summarises the findings and suggests future research directions.

\section{Theoretical underpinnings and related literature}

The broad literature on the climate of doing business and the performance of corporations has been documented for Centuries (Asongu et al., 2014). To articulate the primary themes, Porter (1990, 1998) employs a number of factors from the underpinnings of Adam Smith, namely: the division of labour, economic specialisation and comparative advantage (Stigler, 1957; Smith, 1937[1776]). Motivated by Smith, both regional scientists (e.g. economic geographers) and regional economists (e.g. Paul Krugman) have substantially shown that the efficient allocation of economic resources is determined by both location-specific and basic business costs (Richardson, 1969). Drivers of such costs and corresponding benefits encompass the availability of a plethora of factors, notably: primary production factors (entrepreneurship, capital, labour and land); global and local commodities and money markets; conducive physical and transport infrastructure systems; agglomeration avenues; ICT; social networks and educational amenities such as universities/colleges/schools and libraries. The underpinnings of Porter's model have been supported in more contemporary business literature (Neven \& Droge, 2001).

In spite of the model by Porter, a general theory on the climate of business is characterised with more complexity when compared to the optimal location theory of a business or firm. It is a well known fact businesses are not always established in optimal locations that reflect their higher profits and lowest costs. In SSA, N'da (2012) has investigated the cost of doing business to conclude on nine principal determinants. They include: (i) the ease with which a business is set-up; (ii) obtaining of permits for construction; 
(iii) property rights transfer and enforcement; (iv) security of loans; (v) investor protection; (vi) ease of paying fees and taxes; (vii) cross border trade and other transactions; (viii) compliance with contractual obligations and (ix) the ease with which insolvencies are resolved and other conditions for closing down. Eifert et al. (2005) have assembled both macroeconomic and microeconomic evidence on competitiveness in the African manufacturing sectors to conclude that it is fundamentally determined by the climate of business which influences external economies and comparative advantages of the underlying sectors. They recommended reform in business practices/attitudes because the continent is characterised with high costs relative to its productivity and income.

The business environment in SSA has been studied by Spring et al. (2013) who concluded that appealing economic forces and features include: trade, economic prosperity, foreign direct investment and infrastructure. The authors remarked that the environment of business in SSA is challenging, especially in terms of hurdles in starting business, contract enforcement, control of corruption and regulation quality. Gunning and Mengistae (2001) surveyed the microeconomic evidence on manufacturing investment in the continent during the 1990s. They inferred that the low investment rates are fundamentally due to risky political risky business environments. The assessment by Devarajan et al. (2001) are not in accordance with Gunning and Mengistae (2001) because cross-country and micro data from Tanzania show that investment is not as low in Africa as suggested by the contending authors.

Fafchamps (2001) has reasoned that external transaction and network costs can potentially influence market participants into engaging in unequal and inefficient long-run associations while Stan and Garnsey (2006) have acknowledged that knowledge eases entrepreneurship on the one hand and that entrepreneurship further boosts the growth of knowledge on the other. The underlying reverse causality has been confirmed in more contemporary African literature on KE. Accordingly, Tchamyou (2016) has examined the role of KE in doing business whereas Asongu and Tchamyou (2016) have investigated the influence of entrepreneurship in KE. Both studies have confirmed that causality runs both ways, specifically: from $\mathrm{KE}$ to entrepreneurship and from entrepreneurship to $\mathrm{KE}$ respectively.

Legal perspective of entrepreneurship changes and challenges in the South are documented by Taplin and Synman (2004). The cost of doing business in Africa has been investigated by Eifert et al. (2008) to establish that the indicators of doing business underestimate the performance of African enterprises. This is broadly consistent with the 
conclusions of Paul et al. (2010) which maintain that doing business indicators from the World Bank do not disclose a complete picture of workers' employment. Entrepreneurship in East Africa is for the most part motivated by family and community relationships (Khavul et al., 2009) and trade influences the synchronisation in business cycles (Tapsoba, 2010).

The intension of undergraduate students to become entrepreneurs in Ethiopia was investigated by Gerba (2012) who has established that it is fundamentally influenced by content of business courses. Ita et al. (2014) assessed the factors that affect entrepreneurial objectives among undergraduate students in Southeast and South-south Nigeria. They concluded that personal attitude, perceived barrier and behavioural control are the most significant issues. Other established qualitative influences include: push, affective, personal fulfilment and transformational motivates. Singh et al. (2011) examined the determinants of entrepreneurship among women in Nigeria to conclude on the following motivations: deregulated economic and educational environments, family capital and internally-oriented social recognition. The connection between entrepreneurship and financial literacy in South Africa was studied by Oseifuah (2010) who found that the latter is a crucial driver of the former. The long-term effects of entrepreneurship training were assessed by Mensah and Benedict (2010). They recognised that government policy of distributing handouts with the purpose of reducing poverty has short-run effects for the most part, with potential consequences of violent protests and demonstrations, although entrepreneurship training does provide opportunities for owners of established small corporations to mitigate poverty in the longer term. As discussed in the introduction, this inquiry complements the engaged literature by investigating the interconnections between mobile phones, openness and entrepreneurship in SSA.

\section{Data and Methodology}

\subsection{Data}

This study investigates a panel of forty-nine counties in SSA with data from the World Bank Development Indicators for the period 2000-2012. Whereas the choice of the periodicity is motivated by data availability constraints at the time of writing, the scope of the region is consistent with the motivation discussed in the introductory section. In line with recent entrepreneurship literature (N'da, 2012; Tchamyou, 2016), we use ten indicators of doing business to proxy for entrepreneurship. They comprise: (i) cost of business start-up procedure; (ii) procedure to enforce a contract; (iii) start-up procedures to register a business; (iv) time 
required to build a warehouse; (v) time required to enforce a contract; (vi) time required to register a property; (vii) time required to start a business; (viii) time to export; (ix) time to prepare and pay taxes and (x) time to resolve an insolvency. A decreasing tendency in these variables implies a positive condition for entrepreneurship.

In accordance with Penard et al. (2012) cited in the introduction, ICT is measured with Internet and mobile phone penetration whereas openness (or globalisation) is approximated by trade (imports plus exports of commodities) and financial (foreign direct investment inflows) openness. The rationale for the selection of the globalisation indicators is evidence in the available literature that financial and trade transactions are intuitively linked with ICT (Asongu, 2014a; Amavilah et al., 2017).

In order to account for omitted variable bias, five control variables are used. They are: (i) the lagged dependent variables, (ii) Gross Domestic Product (GDP) growth, (iii) population growth, (iv) educational quality and (v) foreign aid. After a preliminary investigation, adopting more than five control variables leads to the proliferation of instruments which ultimately biases estimated coefficients. Whereas from intuition the lastfour control variables are likely to positively affect the general doing of business environment, their influence on specific entrepreneurship variables is largely contingent on market expansion and dynamism. For example, the relevance of foreign aid is likely to be sensitive to the type of aid and economic sector to which the development assistance is allocated. The perception for these expected signs is consistent with Tchamyou (2016). Education has been documented to affect entrepreneurship by Oseifuah (2010) and Gerba (2012) while GDP growth is naturally expected to be associated with conditions of doing business $^{3}$. Unfortunately, the effect of economic prosperity on the doing of business variables depends on whether GDP growth is skewed towards specific sectors of the economy such as extractive industries. Hence, in the absence of broad-based economic growth, it is likely that less business opportunities are available for the majority of the population. In the same vein, if the growing population depends on imported commodities for the most part, it is likely to bear negatively on the domestic conditions for the doing of business.

\footnotetext{
${ }^{3}$ The choice of 'pupil-teacher ratio' in primary education as a proxy for educational quality is motivated by the documented evidence that compared to other educational levels, primary education is more linked to higher social returns when countries at their initial stages of industrialisation (see Petrakis \& Stamatakis, 2002; Asiedu, 2014).
} 
The definition of the variables and corresponding sources are provided in Appendix 1 whereas the summary statistics are disclosed in Appendix 2. The correlation matrix which is used to inform on potential concerns about multicollinearity is provided in Appendix 3.

\section{2 Methodology}

\subsubsection{Estimation technique}

The inquiry adopts a Generalised Method of Moments (GMM) estimation approach for at least five main reasons. Whereas, the first-two are standard requirements for the adoption of the approach, the last-three are advantages associated with the empirical strategy. First, the estimation approach requires that the doing business variables are persistent. As apparent in Appendix 4, the indicators of doing business are persistent because the correlation between level observations and their corresponding lagged values is higher than the rule of thumb threshold of 0.800. Second, the requirement of the number of countries (N) being higher than the number of years (T) is met because $\mathrm{N}$ (49)>T(13). Third, the estimation technique accounts for endogeneity by controlling for simultaneity and time-invariant omitted variables. Fourth, cross-country differences are not eliminated in the estimation approach. Whereas country-fixed impacts are eliminated in the GMM approach, cross-country variations are automatically considered in the estimations because the technique is by definition consistent to panel data analysis. Fifth, small sample biases in the difference estimator are corrected by the system estimator. It is fundamentally for this fifth reason that Bond et al. (2001, p. 3-4) have maintained that the system GMM technique (Arellano \& Bover, 1995; Blundell \& Bond, 1998) is better than the difference GMM approach (Arellano and Bond, 1991).

In this study, we instead employ the Arellano and Bover (1995) extension by Roodman (2009a, 2009b) which uses forward orthogonal deviations instead of first differences because it has been renowned to restrict instrument proliferation and control for cross-sectional dependence (Baltagi, 2008; Love \& Zicchino, 2006). A two-step specification procedure is adopted because it controls for heteroscedasticity. It is important to note that the one-step approach is homoscedasticity-consistent.

The following equations in levels (1) and first difference (2) summarize the standard system GMM estimation procedure. 
$B_{i, t}=\sigma_{0}+\sigma_{1} B_{i, t-\tau}+\sigma_{2} I C T_{i, t}+\sigma_{3} O p_{i, t}+\sigma_{4} I C T O p_{i, t}+\sum_{h=1}^{4} \delta_{h} W_{h, i, t-\tau}+\eta_{i}+\xi_{t}+\varepsilon_{i, t}$

$$
\begin{aligned}
B_{i, t}-B_{i, t-\tau} & =\sigma_{1}\left(B_{i, t-\tau}-B_{i, t-2 \tau}\right)+\sigma_{2}\left(I C T_{i, t}-I C T_{i, t-\tau}\right)+\sigma_{3}\left(O p_{i, t}-O p_{i, t-\tau}\right)+\sigma_{3}\left(I C T O p_{i, t}-I^{\prime C T O p_{i, t-\tau}}\right) \\
& +\sum_{h=1}^{4} \delta_{h}\left(W_{h, i, t-\tau}-W_{h, i, t-2 \tau}\right)+\left(\xi_{t}-\xi_{t-\tau}\right)+\varepsilon_{i, t-\tau}
\end{aligned}
$$

where, $B_{i, t}$ is a doing business indicator of country $i$ at period $t ; \sigma_{0}$ is a constant; $\tau$ represents the autoregressive order; ICT, (mobile phone and Internet penetration rates); $O p$, openness (trade and foreign direct investment); ICTOp, is the interaction between ICT and openness; $W$ is the vector of control variables (GDP growth, population growth, educational quality and foreign aid), $\eta_{i}$ is the country-specific effect, $\xi_{t}$ is the time-specific constant and $\varepsilon_{i, t}$ the error term. Given that the estimation strategy involves interactive regressions, we conform to Brambor et al. (2006) in including all constituent interactive variables in the specifications.

The main shortcoming of the GMM technique is that the approach eliminates countryspecific impacts which potentially represent the unobserved heterogeneity. Unfortunately, this elimination is necessary to avoid estimation biases. Fortunately however, some level of the unobserved heterogeneity is also considered by the adopted GMM approach because it controls for time-invariant omitted variables. Another potential drawback is that estimated coefficients are interpreted as short-term impacts because, for the most part, the adoption of GMM complies with data averages. In this study, we are not using data averages.

\subsubsection{Identification and exclusion restriction}

Consistent with recent literature (Love \& Zicchino, 2006; Dewan \& Ramaprasad, 2014; Asongu \& Nwachukwu, 2016a, 2016b) all explanatory variables are treated as suspected endogenous or predetermined indicators. Hence, the gmmstyle is adopted for them. Furthermore, only years are treated as exogenous and the approach for treating ivstyle (years) is 'iv(years, eq[diff])' because it is not apparent for the years to become endogenous in firstdifference (Roodman, 2009b).

The concern about simultaneity is tackled by using lagged regressors as instruments for the forward-differenced variables. Consequently, fixed impacts that evidently influence the assessed relationships are eliminated with Helmet transformations that are performed in 
line with Love and Zicchino (2006). Such transformations consist of forward meandifferencing of indicators: contrary to subtracting past observations from present ones (Roodman, 2009b, p. 104), the average of future observations is subtracted from the variables. The transformation enables orthogonal or parallel conditions between lagged variables and forward-differenced indicators. Irrespective of lagged numbers, in order to limit data loss, the transformations are computed for all observations, except for the last in each cross-section. "And because lagged observations do not enter the formula, they are valid as instruments" (Roodman, 2009b, p. 104).

With the above in mind, years or time invariant variables which are hypothesised to exhibit strict exogeneity influence entrepreneurship variables exclusively via endogenous explaining variables. The statistical validity of the exclusion restriction is investigated with the Difference in Hansen Test (DHT) for instrument exogeneity. The null hypothesis of the test should not be rejected for the strictly exogenous instruments (or years) to elucidate the entrepreneurship variables exclusively via the predetermined explanatory variables. The DHT is hence, employed to investigate whether the time invariant variables exhibit strict exogeneity by not explaining entrepreneurship beyond the suggested channels (or endogenous explaining variables). Thus, in the section that follows, the reported findings should confirm the validity of the exclusion restriction if the null hypotheses of DHT corresponding to IV (year, eq[diff]) are not rejected.

\section{Empirical results}

\section{1 Presentation of results}

Table 1, Table 2, Table 3 and Table 4 respectively present the first, second, third and fourth sets of specifications on linkages between ICT, openness and entrepreneurship. Table 1 is concerned with the: (i) cost of business start-up procedures, (ii) procedures to enforce a contract and (iii) start-up procedures to register a business. Table 2 focuses on the: (iv) time required to build a warehouse; (v) time required to enforce a contract and (vi) time required to register a property. In Table 3, emphasis is made on the: (vii) time required to start a business (viii) time to export and (ix) time to prepare and time to pay taxes whereas Table 4 focuses on (x) the time required to resolve an insolvency. For each doing business indicator, there are four specifications: two pertaining to trade openness and two related to financial openness. For either openness indicators, one specification employs the mobile phone penetration policy variable whereas the second specification employs the Internet penetration policy variable. 
Four information criteria are used to investigate the validity of the GMM estimations (Asongu \& De Moor, 2017, p. 200). (i) The null hypothesis of the second-order Arellano and Bond autocorrelation test (AR [2]) which argues for the absence of autocorrelation in the residuals should not be rejected. (ii) The Sargan and Hansen over-identification restrictions (OIR) tests should be insignificant because their null hypotheses are the positions that instruments are valid or uncorrelated with the error terms. Accordingly, whereas the Sargan OIR test is not robust but not weakened by instruments, the Hansen OIR is robust but weakened by instruments. In order to restrict identification or limit the proliferation of instruments, we have ensured that instruments are lower than the number of cross-sections in most specifications. (iii) The Difference in Hansen Test (DHT) for exogeneity of instruments is also employed to examine the validity of results from the Hansen OIR test. (iv) We also provide a Fischer test for the joint validity of estimated coefficients.

In order to assess the role of ICT in modulating the effect of openness on entrepreneurship, the net effect is computed. For example, in Table 1, in the second to the last column, the net effect from the interaction between mobile phones and financial openness on 'start-up procedures to register a business' is $-0.009([0.0004 \times 23.379]+[-0.019])$. Where, the mean value of mobile phone penetration is 23.379 , the unconditional impact of financial openness is -0.019 while the conditional effect from the interaction between financial openness and mobile phones is 0.0004 . 


\section{Table 1: ICT, Openness and Entrepreneurship (First set of specifications)}

Dependent variables: Cost of business start-up procedure, Procedure to enforce a contract and Start-up procedure to register a business

Cost of business start-up procedure (Costostart)

Trade Openness Financial Openness
Procedure to enforce a contract (Contractenf)

Trade Openness Financial Openness
Start-up procedures to register a business (Startupproced)

Trade Openness Financial

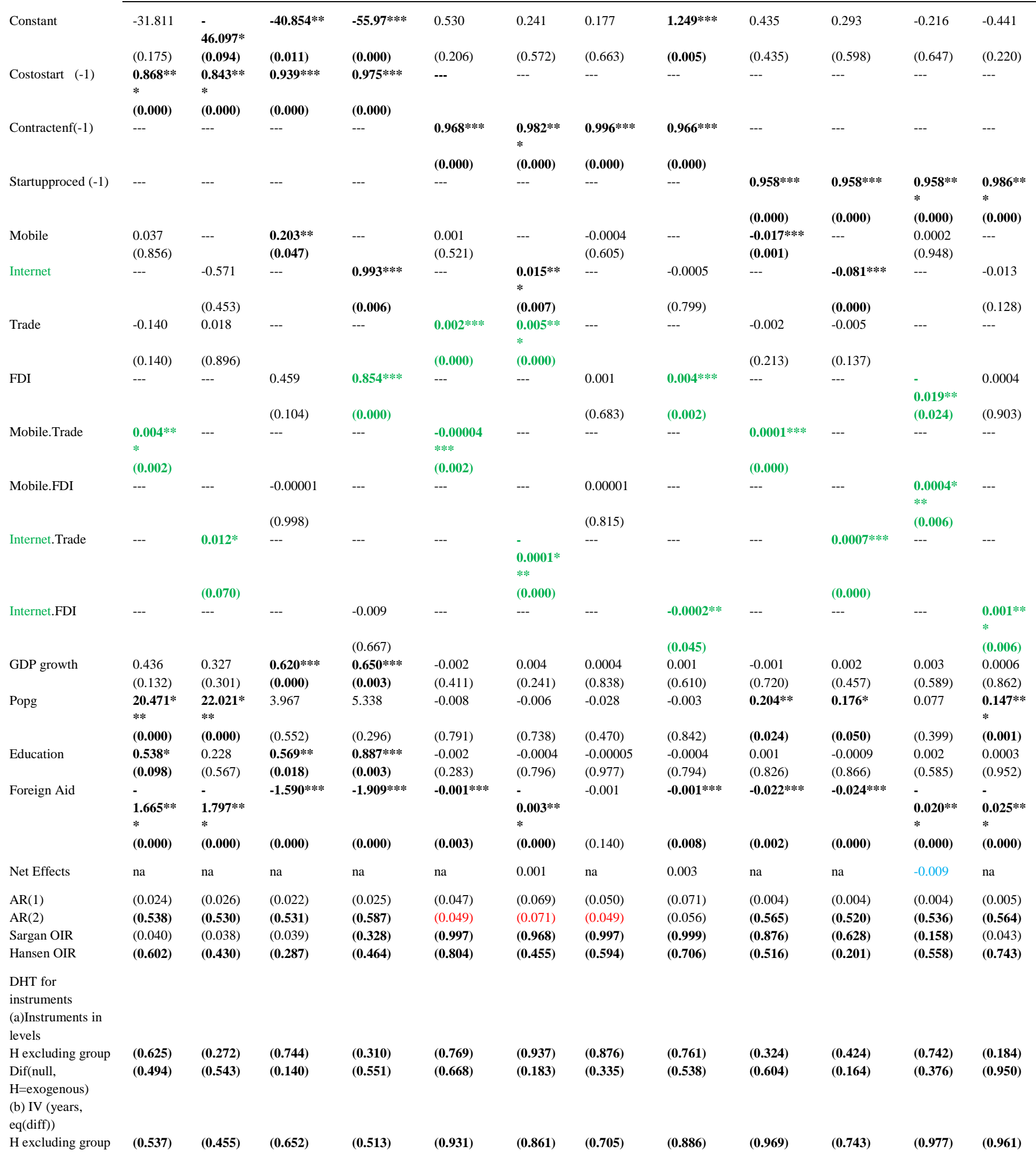




\begin{tabular}{|c|c|c|c|c|c|c|c|c|c|c|c|c|}
\hline $\begin{array}{l}\text { Dif(null, } \\
\text { H=exogenous) }\end{array}$ & $(0.558)$ & $(0.372)$ & $(0.076)$ & $(0.354)$ & $(0.296)$ & $(0.078)$ & $(0.318)$ & $(0.241)$ & $(0.042)$ & $(0.024)$ & $(0.047)$ & $(0.163)$ \\
\hline Fisher & $\begin{array}{l}\text { 722.13* } \\
* *\end{array}$ & $\begin{array}{l}\text { 3199.7* } \\
* *\end{array}$ & $7025.5 * * *$ & $5752.2 * * *$ & $9486.5 * * *$ & $\begin{array}{l}11967 * * \\
*\end{array}$ & $23392 * * *$ & $7864.1 * * *$ & $3412.6 * * *$ & 4495.0*** & $\begin{array}{l}\text { 1878.9* } \\
* *\end{array}$ & $\begin{array}{l}\text { 2221.0* } \\
* *\end{array}$ \\
\hline Instruments & 38 & 38 & 38 & 38 & 38 & 38 & 38 & 38 & 38 & 38 & 38 & 38 \\
\hline Countries & 45 & 44 & 45 & 44 & 45 & 44 & 45 & 44 & 45 & 44 & 45 & 44 \\
\hline Observations & 267 & 262 & 269 & 264 & 267 & 262 & 269 & 264 & 267 & 262 & 269 & 264 \\
\hline
\end{tabular}

***,***: significance levels of 10\%, $5 \%$ and 1\% respectively. DHT: Difference in Hansen Test for Exogeneity of Instruments' Subsets. Dif: Difference. OIR: Over-identifying Restrictions Test. The significance of bold values is twofold. 1) The significance of estimated coefficients, Hausman test and the Fisher statistics. 2) The failure to reject the null hypotheses of: a) no autocorrelation in the AR(1) and AR(2) tests and; b) the validity of the instruments in the OIR and DHT tests. na: not applicable because at least one estimated coefficient needed for the computation of net effects is not significant. The mean value of mobile phone penetration is 23.379 while the mean value of Internet penetration is 4.152 .

\section{Table 2: ICT, Openness and Entrepreneurship (Second set of specifications)}

\begin{tabular}{|c|c|c|c|c|c|c|c|c|c|c|c|c|}
\hline \multirow{5}{*}{ Constant } & \multicolumn{12}{|c|}{$\begin{array}{l}\text { Dependent variables: Time required to build a warehouse, Time required to enforce a contract and Time required to register a } \\
\text { property }\end{array}$} \\
\hline & \multicolumn{4}{|c|}{$\begin{array}{l}\text { Time required to build a warehouse } \\
\text { (Timewarehouse) }\end{array}$} & \multicolumn{4}{|c|}{$\begin{array}{l}\text { Time required to enforce a contract } \\
\text { (Timenforcontr) }\end{array}$} & \multicolumn{4}{|c|}{$\begin{array}{l}\text { Time required to register a property } \\
\text { (Timeregroup) }\end{array}$} \\
\hline & \multicolumn{2}{|c|}{ Trade Openness } & \multicolumn{2}{|c|}{ Financial Openness } & \multicolumn{2}{|c|}{ Trade Openness } & \multicolumn{2}{|c|}{ Financial Openness } & \multicolumn{2}{|c|}{ Trade Openness } & \multicolumn{2}{|c|}{ Financial Openness } \\
\hline & $15.812 * *$ & $\begin{array}{l}47.573 * \\
* *\end{array}$ & 4.400 & $19.593 * * *$ & 63.834* & 9.993 & $112.68 * * *$ & 3.803 & 11.841 & $\begin{array}{l}\text { 32.180* } \\
*\end{array}$ & $14.826 * * *$ & $\begin{array}{l}36.287 * \\
* *\end{array}$ \\
\hline & $(0.029)$ & $(0.001)$ & $(0.483)$ & $(0.006)$ & $(0.060)$ & $(0.680)$ & $(0.000)$ & $(0.713)$ & $(0.113)$ & $(0.017)$ & $(0.006)$ & $(0.000)$ \\
\hline \multirow[t]{2}{*}{$\begin{array}{l}\text { Timewarehouse (- } \\
\text { 1) }\end{array}$} & $0.863^{* * *}$ & $\begin{array}{l}0.852 * * \\
*\end{array}$ & $0.904 * * *$ & $0.874 * * *$ & --- & --- & -- & --- & --- & --- & --- & --- \\
\hline & $(0.000)$ & $(0.000)$ & $(0.000)$ & $(0.000)$ & & & & & & & & \\
\hline \multirow[t]{2}{*}{ Timenforcontr(-1) } & --- & --- & --- & --- & $0.995 * * *$ & $1.028 * * *$ & $0.953 * * *$ & $\begin{array}{l}1.000 * * \\
*\end{array}$ & --- & --- & --- & --- \\
\hline & & & & & $(0.000)$ & $(0.000)$ & $(0.000)$ & $(0.000)$ & & & & \\
\hline \multirow[t]{2}{*}{ Timeregroup(-1) } & --- & --- & --- & --- & --- & --- & --- & --- & $\begin{array}{l}\mathbf{0 . 8 6 1} * * \\
*\end{array}$ & $\begin{array}{l}\mathbf{0 . 7 9 7} * * \\
*\end{array}$ & $0.843 * * *$ & $\begin{array}{l}\mathbf{0 . 7 3 0} * * \\
*\end{array}$ \\
\hline & & & & & & & & & $(0.000)$ & $(0.000)$ & $(0.000)$ & $(0.000)$ \\
\hline Mobile & $\begin{array}{l}0.164 * \\
(0.086)\end{array}$ & --- & $\begin{array}{l}0.169 * * * \\
(0.002)\end{array}$ & --- & $\begin{array}{l}-0.473 * * \\
(0.013)\end{array}$ & --- & $\begin{array}{l}-\mathbf{0 . 7 1 8} * * * \\
(0.000)\end{array}$ & --- & $\begin{array}{l}-0.015 \\
(0.869)\end{array}$ & --- & $\begin{array}{l}-0.074 * \\
(0.065)\end{array}$ & --- \\
\hline \multirow[t]{2}{*}{ Internet } & --- & -0.094 & -- & -0.050 & -- & $-2.591 * * *$ & --- & $\begin{array}{l}- \\
1.393 * * \\
*\end{array}$ & --- & $1.012 * *$ & --- & $\begin{array}{l}- \\
0.754 * * \\
*\end{array}$ \\
\hline & & $(0.795)$ & & $(0.775)$ & & $(0.000)$ & & $(0.000)$ & & $(0.013)$ & & $(0.000)$ \\
\hline \multirow[t]{2}{*}{ Trade } & $-0.068 *$ & $0.195 * *$ & --- & --- & -0.036 & $-0.320 * *$ & --- & --- & 0.116** & $\begin{array}{l}- \\
0.174 * * \\
*\end{array}$ & --- & --- \\
\hline & $(0.067)$ & $(0.011)$ & & & $(0.700)$ & $(0.029)$ & & & $(0.048)$ & $(0.008)$ & & \\
\hline \multirow[t]{2}{*}{ FDI } & --- & --- & $0.695 * * *$ & -0.031 & --- & --- & $-1.620 * * *$ & $\begin{array}{l}- \\
0.963 * * \\
*\end{array}$ & --- & --- & $-0.320^{* * *}$ & $\begin{array}{l}- \\
0.311^{* * *} \\
*\end{array}$ \\
\hline & & & $(0.000)$ & $(0.521)$ & & & $(0.003)$ & $(0.000)$ & & & $(0.017)$ & $(0.000)$ \\
\hline Mobile.Trade & $\begin{array}{l}0.00004 \\
(0.948)\end{array}$ & --- & --- & --- & $\begin{array}{l}0.0007 \\
(0.601)\end{array}$ & --- & --- & --- & $\begin{array}{l}0.0005 \\
(0.586)\end{array}$ & --- & --- & --- \\
\hline Mobile.FDI & --- & --- & $\begin{array}{l}-0.012 * * * \\
(0.000)\end{array}$ & --- & --- & --- & $\begin{array}{l}0.041 * * * \\
(0.002)\end{array}$ & --- & --- & --- & $\begin{array}{l}0.003^{*} \\
(0.085)\end{array}$ & --- \\
\hline Internet.Trade & --- & $\begin{array}{l}0.0008 \\
(0.718)\end{array}$ & --- & --- & --- & $\begin{array}{l}0.031 * * * \\
(0.000)\end{array}$ & --- & --- & --- & $\begin{array}{l}0.007 * * \\
(0.029)\end{array}$ & --- & --- \\
\hline Internet.FDI & --- & --- & --- & $0.024 * * *$ & --- & --- & --- & $\begin{array}{l}0.265 * * \\
*\end{array}$ & --- & --- & --- & $\begin{array}{l}0.016 * * \\
*\end{array}$ \\
\hline \multirow[t]{2}{*}{ GDP growth } & 0.040 & -0.064 & -0.085 & $\begin{array}{l}(0.005) \\
0.058\end{array}$ & $1.225 * * *$ & $1.141 * * *$ & $1.085^{* * * *}$ & $\begin{array}{l}(0.000) \\
1.720 * * \\
*\end{array}$ & 0.210 & 0.251 & $0.386^{* * * *}$ & $\begin{array}{l}(0.007) \\
0.316\end{array}$ \\
\hline & $(0.726)$ & $(0.557)$ & $(0.419)$ & $(0.647)$ & $(0.001)$ & (0.006) & $(0.000)$ & $(0.000)$ & $(0.250)$ & $(0.171)$ & $(0.005)$ & $(0.141)$ \\
\hline Popg & $\begin{array}{l}0.109 \\
(0.927)\end{array}$ & $\begin{array}{l}-1.527 * \\
(0.072)\end{array}$ & $\begin{array}{l}2.663 * \\
(0.057)\end{array}$ & $\begin{array}{l}-0.075 \\
(0.955)\end{array}$ & $\begin{array}{l}-9.126 * * * * \\
(0.001)\end{array}$ & $\begin{array}{l}-9.036 * * * \\
(0.000)\end{array}$ & $\begin{array}{l}-6.607 * \\
(0.062)\end{array}$ & $\begin{array}{l}0.628 \\
(0.768)\end{array}$ & $\begin{array}{l}0.860 \\
(0.514)\end{array}$ & $\begin{array}{l}1.146 \\
(0.472)\end{array}$ & $\begin{array}{l}2.380^{*} \\
(0.097)\end{array}$ & $\begin{array}{l}1.879 * \\
(0.080)\end{array}$ \\
\hline Education & $0.325 *$ & -0.073 & $0.139 *$ & 0.143 & -0.383 & 0.187 & $-0.784 * * *$ & - & -0.074 & -0.172 & $-0.250 * * *$ & - \\
\hline & $(0.054)$ & $(0.675)$ & $(0.092)$ & $(0.210)$ & $(0.259)$ & $(0.496)$ & $(0.000)$ & $(0.021)$ & $(0.569)$ & $(0.284)$ & $(0.007)$ & $(0.010)$ \\
\hline Foreign Aid & $-0.392 * * *$ & $0.319 * *$ & $-0.519 * * *$ & $-0.433 * * *$ & -0.065 & 0.031 & -0.105 & -0.061 & 0.059 & $0.107^{*}$ & 0.066 & 0.033 \\
\hline
\end{tabular}




\begin{tabular}{|c|c|c|c|c|c|c|c|c|c|c|c|c|}
\hline & $(0.000)$ & $\begin{array}{l}* \\
(0.000)\end{array}$ & $(0.000)$ & $(0.000)$ & $(0.379)$ & $(0.714)$ & $(0.506)$ & $(0.737)$ & $(0.498)$ & $(0.060)$ & $(0.152)$ & $(0.222)$ \\
\hline Net Effects & na & na & 0.414 & na & na & -0.191 & -0.661 & 0.137 & na & -0.144 & -0.249 & -0.244 \\
\hline $\mathrm{AR}(1)$ & $(0.136)$ & $(0.143)$ & $(0.127)$ & $(0.132)$ & $(0.101)$ & $(0.120)$ & $(0.091)$ & $(0.085)$ & $(0.061)$ & $(0.070)$ & $(0.064)$ & $(0.076)$ \\
\hline $\operatorname{AR}(2)$ & $(0.114)$ & $(0.194)$ & $(0.147)$ & $(0.213)$ & $(0.694)$ & $(0.437)$ & $(0.417)$ & $(0.349)$ & $(0.204)$ & $(0.193)$ & $(0.239)$ & $(0.131)$ \\
\hline Sargan OIR & $(0.664)$ & $(0.512)$ & $(0.208)$ & $(0.077)$ & $(0.325)$ & $(0.091)$ & $(0.162)$ & $(0.307)$ & $(0.760)$ & $(\mathbf{0 . 8 3 3})$ & $(0.932)$ & $(0.944)$ \\
\hline Hansen OIR & $(0.642)$ & $(0.763)$ & $(0.824)$ & $(0.788)$ & $(0.870)$ & $(0.706)$ & $(0.377)$ & $(0.097)$ & $(0.974)$ & $(0.946)$ & $(0.908)$ & $(0.659)$ \\
\hline \multicolumn{13}{|l|}{$\begin{array}{l}\text { DHT for } \\
\text { instruments } \\
\text { (a)Instruments in } \\
\text { levels }\end{array}$} \\
\hline $\mathrm{H}$ excluding group & $(0.732)$ & $(0.501)$ & $(0.700)$ & $(0.718)$ & $(0.404)$ & $(0.502)$ & $(0.296)$ & $(0.129)$ & $(0.851)$ & $(0.786)$ & $(0.777)$ & $(0.501)$ \\
\hline $\begin{array}{l}\text { Dif(null, } \\
\text { H=exogenous) } \\
\text { (b) IV (years, } \\
\text { eq(diff)) }\end{array}$ & $(0.477)$ & $(0.776)$ & $(0.741)$ & $(0.677)$ & $(0.939)$ & $(0.703)$ & $(0.451)$ & $(0.182)$ & $(0.936)$ & $(0.899)$ & $(0.834)$ & (0.646) \\
\hline $\mathrm{H}$ excluding group & $(0.486)$ & $(0.742)$ & $(0.661)$ & $(0.905)$ & $(0.838)$ & $(0.667)$ & 0.459) & $(0.202)$ & $(0.938)$ & $(0.801)$ & $(0.909)$ & $(0.460)$ \\
\hline $\begin{array}{l}\text { Dif(null, } \\
\text { H=exogenous) }\end{array}$ & $(0.776)$ & $(0.538)$ & $(0.882)$ & $(0.253)$ & $(0.644)$ & $(0.558)$ & $(0.286)$ & $(0.111)$ & $(0.849)$ & $(0.967)$ & $(0.584)$ & $(0.823)$ \\
\hline Fisher & $2178.4 * * *$ & $\begin{array}{l}1374.5 * \\
* *\end{array}$ & $880.26 * * *$ & $3115.8 * * *$ & $5878.7 * * *$ & $14160 * * *$ & $15754 * * *$ & $\begin{array}{l}23541 * * \\
*\end{array}$ & $\begin{array}{l}\text { 629.17* } \\
* *\end{array}$ & $\begin{array}{l}\text { 651.30* } \\
* *\end{array}$ & $1588.7 * * *$ & $\begin{array}{l}\text { 807.74* } \\
* *\end{array}$ \\
\hline Instruments & 36 & 36 & 36 & 36 & 38 & 38 & 38 & 38 & 37 & 37 & 37 & 37 \\
\hline Countries & 44 & 43 & 44 & 43 & 45 & 44 & 45 & 44 & 45 & 44 & 45 & 44 \\
\hline Observations & 205 & 200 & 207 & 202 & 267 & 262 & 269 & 264 & 241 & 236 & 243 & 238 \\
\hline
\end{tabular}

*******: significance levels of 10\%, 5\% and 1\% respectively. DHT: Difference in Hansen Test for Exogeneity of Instruments' Subsets. Dif: Difference. OIR: Over-identifying Restrictions Test. The significance of bold values is twofold. 1) The significance of estimated coefficients, Hausman test and the Fisher statistics. 2) The failure to reject the null hypotheses of: a) no autocorrelation in the AR(1) and AR(2) tests and; b) the validity of the instruments in the OIR and DHT tests. na: not applicable because at least one estimated coefficient needed for the computation of net effects is not significant. The mean value of mobile phone penetration is 23.379 while the mean value of Internet penetration is 4.152 .

\section{Table 3: ICT, Openness and Entrepreneurship (Third set of specifications)}

\begin{tabular}{|c|c|c|c|c|c|c|c|c|c|c|c|c|}
\hline \multirow[b]{4}{*}{ Constant } & \multicolumn{12}{|c|}{ Dependent variables: Time required to start a business, Time to exports and Time to prepare and pay taxes } \\
\hline & \multicolumn{4}{|c|}{$\begin{array}{l}\text { Time required to start a business } \\
\text { (Timestartbus) }\end{array}$} & \multicolumn{4}{|c|}{ Time to export (Timexport) } & \multicolumn{4}{|c|}{$\begin{array}{c}\text { Time to prepare and pay taxes } \\
\text { (Timetaxes) }\end{array}$} \\
\hline & \multicolumn{2}{|c|}{ Trade Openness } & \multicolumn{2}{|c|}{ Financial Openness } & \multicolumn{2}{|c|}{ Trade Openness } & \multicolumn{2}{|c|}{ Financial Openness } & \multicolumn{2}{|c|}{ Trade Openness } & \multicolumn{2}{|c|}{$\begin{array}{l}\text { Financial } \\
\text { Openness }\end{array}$} \\
\hline & -7.543 & -4.997 & $-14.58 * * *$ & $-13.51 * * *$ & - & $-5.830 * * *$ & -1.805 & $2.289 * *$ & 12.016 & 20.406 & 1.393 & 4.933 \\
\hline & $(0.289)$ & $(0.300)$ & $(0.000)$ & $(0.000)$ & $\begin{array}{r}3.653 * * \\
(0.032)\end{array}$ & $(0.001)$ & $(0.284)$ & $(0.038)$ & $(0.461)$ & $(0.283)$ & $(0.851)$ & $(0.732)$ \\
\hline Timestartbus(-1) & $\begin{array}{l}1.132 * * * \\
(0.000)\end{array}$ & $\begin{array}{l}1.063 * * * \\
(0.000)\end{array}$ & $\begin{array}{l}0.898 * * * \\
(0.000)\end{array}$ & $\begin{array}{l}0.970 * * \\
(0.000)\end{array}$ & --- & --- & --- & --- & --- & --- & --- & --- \\
\hline Timexport(-1) & --- & --- & --- & --- & $\begin{array}{l}\mathbf{0 . 9 7 0} * * \\
*\end{array}$ & & & & --- & --- & --- & --- \\
\hline & & & & & $(0.000)$ & $(0.000)$ & $(0.000)$ & $(0.000)$ & & & & \\
\hline Timetaxes(-1) & --- & --- & --- & --- & --- & --- & --- & --- & $\begin{array}{l}1.031 * * \\
* \\
(0.000)\end{array}$ & $\begin{array}{l}1.039 * * \\
* \\
(0.000)\end{array}$ & $\begin{array}{l}1.013 * * \\
* \\
(0.000)\end{array}$ & $\begin{array}{l}1.017 * * \\
* \\
(0.000)\end{array}$ \\
\hline Mobile & $\begin{array}{l}-0.045 \\
(0.539)\end{array}$ & --- & $\begin{array}{l}0.063^{*} \\
(0.065)\end{array}$ & --- & $\begin{array}{l}0.026^{*} \\
(0.095)\end{array}$ & --- & $\begin{array}{l}0.016 \\
(0.117)\end{array}$ & --- & $\begin{array}{l}-0.201 * \\
(0.082)\end{array}$ & --- & $\begin{array}{l}-0.039 \\
(0.479)\end{array}$ & --- \\
\hline Internet & --- & $\begin{array}{l}-0.633^{* * * *} \\
(0.004)\end{array}$ & --- & $\begin{array}{l}0.044 \\
(0.582)\end{array}$ & --- & $\begin{array}{l}-0.005 \\
(0.924)\end{array}$ & --- & $\begin{array}{l}-\mathbf{- 0 . 0 8 8} * * * \\
(\mathbf{0 . 0 0 3 )}\end{array}$ & --- & $\begin{array}{l}-1.014 * \\
(0.079)\end{array}$ & --- & $\begin{array}{l}0.092 \\
(0.781)\end{array}$ \\
\hline Trade & $-0.114 * * *$ & $-0.192 * * * *$ & --- & --- & $\begin{array}{l}0.021 * * \\
*\end{array}$ & $0.035 * * *$ & --- & --- & $\begin{array}{l}- \\
0.253 * * \\
*\end{array}$ & $0.188 * *$ & --- & --- \\
\hline & $(0.003)$ & $(0.000)$ & & & $(0.003)$ & $(0.001)$ & & & $(0.001)$ & $(0.047)$ & & \\
\hline FDI & --- & --- & $\begin{array}{l}0.267 * * * \\
(0.000)\end{array}$ & $\begin{array}{l}0.091 * \\
(0.054)\end{array}$ & --- & --- & $\begin{array}{l}0.013 \\
(0.704)\end{array}$ & $\begin{array}{l}-0.026 * * * * \\
(0.006)\end{array}$ & --- & --- & $\begin{array}{l}-0.179 \\
(0.143)\end{array}$ & $\begin{array}{l}-0.025 \\
(0.763)\end{array}$ \\
\hline
\end{tabular}




\begin{tabular}{|c|c|c|c|c|c|c|c|c|c|c|c|c|}
\hline \multirow[t]{2}{*}{ Mobile.Trade } & $0.001 * *$ & --- & --- & --- & -0.0001 & --- & --- & --- & $\begin{array}{l}\mathbf{0 . 0 0 2} * * \\
*\end{array}$ & --- & --- & --- \\
\hline & $(0.038)$ & & & & $(0.432)$ & & & & $(0.001)$ & & & \\
\hline Mobile.FDI & --- & --- & $\begin{array}{l}-0.002 * \\
(0.070)\end{array}$ & --- & --- & --- & $\begin{array}{l}-0.0003 \\
(0.647)\end{array}$ & --- & --- & --- & $\begin{array}{l}0.002 \\
(0.319)\end{array}$ & --- \\
\hline Internet.Trade & --- & $\begin{array}{l}0.009 * * * \\
(0.000)\end{array}$ & --- & --- & --- & $\begin{array}{l}-0.0001 \\
(0.799)\end{array}$ & --- & --- & --- & $\begin{array}{l}0.009 * * \\
(0.025)\end{array}$ & --- & --- \\
\hline Internet.FDI & --- & --- & --- & $\begin{array}{l}0.019 * * \\
(0.019)\end{array}$ & --- & --- & --- & $\begin{array}{l}0.002 \\
(0.272)\end{array}$ & --- & --- & --- & $\begin{array}{l}-0.005 \\
(0.470)\end{array}$ \\
\hline \multirow[t]{2}{*}{ GDP growth } & $0.382 * * *$ & $0.124 *$ & 0.036 & 0.086 & $-\overline{0.062 * *}$ & -0.032 & $-0.061 *$ & $-0.102 * * *$ & -0.216 & -0.205 & $-0.177 *$ & 0.269** \\
\hline & $(0.000)$ & $(0.096)$ & $(0.664)$ & $(0.148)$ & $(0.044)$ & $(0.183)$ & $(0.077)$ & $(0.002)$ & $(0.244)$ & $(0.241)$ & $(0.075)$ & $(0.030)$ \\
\hline Popg & $\begin{array}{l}-0.957 \\
(0.322)\end{array}$ & $\begin{array}{l}0.767 \\
(0.108)\end{array}$ & $\begin{array}{l}2.279 * * \\
(0.018)\end{array}$ & $\begin{array}{l}3.240 * * * \\
(0.000)\end{array}$ & $\begin{array}{l}0.058 \\
(0.801)\end{array}$ & $\begin{array}{l}0.173 \\
(0.233)\end{array}$ & $\begin{array}{l}-0.541 * * \\
(0.032)\end{array}$ & $\begin{array}{l}-0.772 * * * \\
(0.009)\end{array}$ & $\begin{array}{l}0.393 \\
(0.724)\end{array}$ & $\begin{array}{l}0.748 \\
(0.678)\end{array}$ & $\begin{array}{l}1.036 \\
(0.268)\end{array}$ & $\begin{array}{l}0.821 \\
(0.581)\end{array}$ \\
\hline Education & $\begin{array}{l}0.216 * * \\
(0.048)\end{array}$ & $\begin{array}{l}0.244 * * * \\
(0.001)\end{array}$ & $\begin{array}{l}0.153 * * * \\
(0.005)\end{array}$ & $\begin{array}{l}0.095 * * \\
(0.015)\end{array}$ & $\begin{array}{l}0.045 \\
(0.141)\end{array}$ & $\begin{array}{l}0.030 \\
(0.223)\end{array}$ & $\begin{array}{l}0.086 * * * \\
(0.006)\end{array}$ & $\begin{array}{l}0.0005 \\
(0.982)\end{array}$ & $\begin{array}{l}-0.183 \\
(0.484)\end{array}$ & $\begin{array}{l}-0.477 * \\
(0.064)\end{array}$ & $\begin{array}{l}-0.204 \\
(0.225)\end{array}$ & $\begin{array}{l}-0.282 \\
(0.230)\end{array}$ \\
\hline \multirow[t]{2}{*}{ Foreign Aid } & $-0.155 * * *$ & $-0.104 * * *$ & $-0.320 * * *$ & $-0.320 * * *$ & 0.006 & -0.007 & $0.026 * *$ & $0.028 * *$ & $\begin{array}{l}0.213 * * \\
*\end{array}$ & $0.159 * *$ & $0.050 *$ & 0.043 \\
\hline & $(0.001)$ & $(0.000)$ & $(0.000)$ & $(0.000)$ & $(0.223)$ & $(0.386)$ & $(0.022)$ & $(0.011)$ & $(0.001)$ & $(0.028)$ & $(0.057)$ & $(0.255)$ \\
\hline Net Effects & -0.090 & -0.154 & 0.220 & 0.169 & na & na & na & na & -0.206 & -0.150 & na & na \\
\hline $\operatorname{AR}(1)$ & $(0.078)$ & $(0.088)$ & $(0.072)$ & $(0.076)$ & $(0.008)$ & $(0.034)$ & $(0.014)$ & $(0.035)$ & $(0.112)$ & $(0.110)$ & $(0.110)$ & $(0.105)$ \\
\hline $\mathrm{AR}(2)$ & $(0.460)$ & $(0.510)$ & $(0.503)$ & $(0.444)$ & $(0.506)$ & $(0.751)$ & $(0.350)$ & $(0.963)$ & $(0.179)$ & $(0.187)$ & $(0.168)$ & $(0.199)$ \\
\hline Sargan OIR & $(0.157)$ & $(0.011)$ & $(0.000)$ & $(0.000)$ & $(0.385)$ & $(0.850)$ & $(0.635)$ & $(0.941)$ & $(0.989)$ & $(0.999)$ & $(0.951)$ & $(0.998)$ \\
\hline Hansen OIR & $(0.652)$ & $(\mathbf{0 . 8 3 2})$ & $(0.406)$ & $(0.621)$ & $(\mathbf{0 . 5 3 0})$ & $(0.823)$ & $(0.216)$ & $(0.198)$ & $(0.375)$ & $(\mathbf{0 . 7 5 3 )}$ & $(0.737)$ & $(0.903)$ \\
\hline \multicolumn{13}{|l|}{$\begin{array}{l}\text { DHT for } \\
\text { instruments } \\
\text { (a)Instruments in } \\
\text { levels }\end{array}$} \\
\hline $\mathrm{H}$ excluding group & $(0.524)$ & $(0.193)$ & $(0.284)$ & $(0.279)$ & $(0.125)$ & $(0.950)$ & $(0.418)$ & $(0.495)$ & $(0.726)$ & $(0.676)$ & $(0.292)$ & $(0.985)$ \\
\hline $\begin{array}{l}\text { Dif(null, } \\
\text { H=exogenous) } \\
\text { (b) IV (years, } \\
\text { eq(diff)) }\end{array}$ & $(0.622)$ & $(0.984)$ & $(0.500)$ & $(0.770)$ & $(0.848)$ & $(0.550)$ & $(0.181)$ & $(0.138)$ & $(0.213)$ & $(0.654)$ & $(0.878)$ & $(0.638)$ \\
\hline H excluding group & $(\mathbf{0 . 7 3 8})$ & $(0.801)$ & $(0.609)$ & $(0.525)$ & $(0.591)$ & $(0.714)$ & $(0.131)$ & $(0.245)$ & $(0.395)$ & $(0.754)$ & $(0.758)$ & $(0.814)$ \\
\hline $\begin{array}{l}\text { Dif(null, } \\
\text { H=exogenous) }\end{array}$ & $(0.362)$ & $(0.615)$ & $(0.188)$ & $(0.612)$ & $(0.327)$ & $(0.773)$ & $(0.656)$ & $(0.239)$ & $(\mathbf{0 . 3 5 0})$ & $(0.505)$ & $(0.442)$ & $(0.824)$ \\
\hline Fisher & $1644.5 * * *$ & $2476.5 * * *$ & $2271.0 * * *$ & $1150.8 * * *$ & $\begin{array}{l}\text { 293.75* } \\
* *\end{array}$ & $1890.6 * * *$ & $961.32 * * *$ & $7669.3 * * *$ & $\begin{array}{l}\text { 4017.4* } \\
* *\end{array}$ & $\begin{array}{l}\mathbf{5 3 3 4 . 5} * \\
* *\end{array}$ & $\begin{array}{l}\text { 5317.9* } \\
* *\end{array}$ & $\begin{array}{l}3340.3 * \\
* *\end{array}$ \\
\hline Instruments & 38 & 38 & 38 & 38 & 36 & 36 & 36 & 36 & 36 & 36 & 36 & 36 \\
\hline Countries & 45 & 44 & 45 & 44 & 45 & 44 & 45 & 44 & 45 & 44 & 45 & 44 \\
\hline Observations & 267 & 262 & 269 & 164 & 211 & 206 & 213 & 208 & 211 & 206 & 213 & 208 \\
\hline
\end{tabular}

*,**,***: significance levels of 10\%, 5\% and 1\% respectively. DHT: Difference in Hansen Test for Exogeneity of Instruments' Subsets. Dif: Difference. OIR: Over-identifying Restrictions Test. The significance of bold values is twofold. 1) The significance of estimated coefficients, Hausman test and the Fisher statistics. 2) The failure to reject the null hypotheses of: a) no autocorrelation in the AR(1) and AR(2) tests and; b) the validity of the instruments in the OIR and DHT tests. na: not applicable because at least one estimated coefficient needed for the computation of net effects is not significant. The mean value of mobile phone penetration is 23.379 while the mean value of Internet penetration is 4.152 . 
Table 4: ICT, Openness and Entrepreneurship (Fourth set of specifications)

\begin{tabular}{|c|c|c|c|c|}
\hline \multirow{4}{*}{ Constant } & \multicolumn{4}{|c|}{ Time to resolve insolvency (Timeresinsolv) } \\
\hline & \multicolumn{2}{|c|}{ Trade Openness } & \multicolumn{2}{|c|}{ Financial Openness } \\
\hline & $-0.044 * * *$ & 0.0002 & $-0.023 * * *$ & $0.009 * * *$ \\
\hline & $(0.000)$ & $(0.972)$ & $(0.000)$ & $(0.000)$ \\
\hline \multirow[t]{2}{*}{ Timeresinsolv (-1) } & $1.010 * * *$ & $1.000 * * *$ & $1.007 * * *$ & $0.999 * * *$ \\
\hline & $(0.000)$ & $(\mathbf{0 . 0 0 )}$ & $(0.000)$ & $(0.000)$ \\
\hline \multirow[t]{2}{*}{ Mobile } & 0.00006 & --- & 0.00009 & --- \\
\hline & $(0.539)$ & & $(0.188)$ & \\
\hline \multirow[t]{2}{*}{ Internet } & --- & 0.0001 & --- & -0.0001 \\
\hline & & $(0.676)$ & & $(0.183)$ \\
\hline \multirow[t]{2}{*}{ Trade } & $0.00007 * *$ & -0.00001 & --- & --- \\
\hline & $(\mathbf{0 . 0 2 3})$ & $(0.710)$ & & \\
\hline \multirow[t]{2}{*}{ FDI } & --- & --- & 0.0001 & -0.00004 \\
\hline & & & $(0.372)$ & $(0.517)$ \\
\hline \multirow[t]{2}{*}{ Mobile.Trade } & 0.0000001 & --- & --- & --- \\
\hline & $(0.727)$ & & & \\
\hline \multirow[t]{2}{*}{ Mobile.FDI } & --- & --- & -0.000002 & --- \\
\hline & & & $(0.311)$ & \\
\hline \multirow[t]{2}{*}{ Internet.Trade } & --- & -0.0000001 & --- & --- \\
\hline & & $(0.926)$ & & \\
\hline \multirow[t]{2}{*}{ Internet.FDI } & --- & 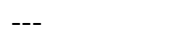 & --- & 0.000004 \\
\hline & & & & $(0.446)$ \\
\hline \multirow[t]{2}{*}{ GDP growth } & -0.0001 & -0.0001 & $-0.0003 * *$ & -0.0001 \\
\hline & $(0.550)$ & $(0.447)$ & $(\mathbf{0 . 0 2 8})$ & $(0.265)$ \\
\hline \multirow[t]{2}{*}{ Popg } & 0.0005 & -0.0002 & $0.001 *$ & -0.0002 \\
\hline & $(0.536)$ & $(0.796)$ & $(0.081)$ & $(0.814)$ \\
\hline \multirow[t]{2}{*}{ Education } & 0.00005 & 0.00003 & -0.00009 & -0.0001 \\
\hline & $(0.634)$ & $(0.811)$ & $(0.236)$ & $(0.143)$ \\
\hline Foreign Aid & --- & --- & --- & --- \\
\hline Net Effects & na & na & na & na \\
\hline $\operatorname{AR}(1)$ & $(0.317)$ & $(0.317)$ & $(0.316)$ & $(0.317)$ \\
\hline $\operatorname{AR}(2)$ & $(0.307)$ & $(0.761)$ & $(0.562)$ & $(0.767)$ \\
\hline Sargan OIR & $(0.999)$ & (1.000) & $(0.987)$ & $(1.000)$ \\
\hline Hansen OIR & $(0.980)$ & (1.000) & $(0.956)$ & (1.000) \\
\hline \multicolumn{5}{|l|}{$\begin{array}{l}\text { DHT for instruments } \\
\text { (a)Instruments in levels }\end{array}$} \\
\hline H excluding group & $(0.978)$ & $(0.984)$ & $(0.981)$ & $(0.983)$ \\
\hline Dif(null, $\mathrm{H}=$ exogenous) & $(0.882)$ & (1.000) & $(0.793)$ & $(1.000)$ \\
\hline \multicolumn{5}{|l|}{ (b) IV (years, eq(diff)) } \\
\hline H excluding group & $(0.998)$ & (1.000) & $(0.998)$ & $(1.000)$ \\
\hline Dif(null, $\mathrm{H=exogenous)}$ & $(0.538)$ & (0.999) & $(0.399)$ & $(0.994)$ \\
\hline Fisher & $384868.52 * * *$ & $1.57 \mathbf{e}+06 * * *$ & $458145.61 * * *$ & $1.25 \mathrm{e}+07 * * *$ \\
\hline Instruments & 34 & 34 & 34 & 34 \\
\hline Countries & 38 & 37 & 38 & 37 \\
\hline Observations & 232 & 228 & 234 & 230 \\
\hline
\end{tabular}

***,***: significance levels of 10\%, 5\% and 1\% respectively. DHT: Difference in Hansen Test for Exogeneity of Instruments' Subsets. Dif: Difference. OIR: Over-identifying Restrictions Test. The significance of bold values is twofold. 1) The significance of estimated coefficients, Hausman test and the Fisher statistics. 2) The failure to reject the null hypotheses of: a) no autocorrelation in the $\operatorname{AR}(1)$ and $\operatorname{AR}(2)$ tests and; b) the validity of the instruments in the OIR and DHT tests. na: not applicable because at least one estimated coefficient needed for the computation of net effects is not significant. The mean value of mobile phone penetration is 23.379 while the mean value of Internet penetration is 4.152 . 
The following findings can be established from Tables 1-4. First, net effects on the 'cost of business start-up procedure', 'time to export' and 'time to resolve an insolvency' from the interaction of ICT with openness are not apparent because at least one estimate required for their computations is not significant. Second, there are positive net effects from the role of the Internet on openness (trade and FDI) in the number of procedures required to enforce a contract. Third, the net effect from the interaction between mobile phones and financial openness on the 'number start-up procedures to register a business' is negative. Fourth, mobile phone (Internet) penetration interacts with financial openness to have positive net effect on the 'time required to build a warehouse' (time required to enforce a contract). Fifth, trade (FDI) interacts with the Internet (mobile phones) to have a net effect in reducing the time required to enforce a contract whereas for the most part, ICT complements openness to reduce the time required to register a property. Sixth, ICT interacts with trade openness to have net negative effects on the 'time required to start a business' and the 'time required to prepare and pay taxes'.

\subsection{Further discussion of results and policy implications}

\subsubsection{Further discussion of results and practical implications}

As apparent from the findings while there is substantial evidence that ICT complements openness to improve conditions for entrepreneurship, the effects are contingent on the dynamics of openness, ICT and entrepreneurship. The findings broadly suggest that transparency through ICT is important in the effect of openness on doing business constraints. The relevance of ICT in facilitating the doing of business is consistent with intuition and the literature because ICT contributes to enhancing competition, essentially because of falling cost/traffic per minute and positive externalities owing to network avenues (Gutierrez et al., 2009; Gille et al., 2002 ; Esselaar et al., 2007 ; Gilwald \& Stork, 2008).

We have also established insignificant net estimates on constraints to doing business. This pattern of the findings is consistent with a recent co-publication by the International Finance Corporation and the World Bank on 'Doing Business in the East African Community' (World Bank, 2013) which shows that among 185 countries only ten countries in SSA rank among the top one hundred in terms of ease of doing business. The next set of a small group of countries fall between the $109^{\text {th }}$ and $134^{\text {th }}$ places while for the most part, countries in the sub-region rank after the $169^{\text {th }}$ position. Whereas the World Bank report does 
not consider ICT as the primary factor, ICT is among the several determinants for the ease of doing business.

The insignificant net effects are an indication that ICT penetration needs to be enhanced. This is essentially because the corresponding marginal effects for the most part are negative on the constraints to doing business, notably the interaction between: (i) Internet and both openness indicators in the number of procedures required to enforce a contract and (ii) FDI and mobile phones on the time required to build a warehouse and the time required to start a business. In essence, certain thresholds of ICT penetration are required to achieve the desirable negative effects on constraints to doing business. To put this point into perspective, in Table 1: (i) $50(0.005 / 0.0001)$ per 100 people in Internet penetration and (ii) 20 $(0.004 / 0.0002)$ per 100 people in Internet penetration are required to respectively reverse the positive effects of trade and FDI on the number of procedures required to enforce a contract. In Table 2, $57.916(0.695 / 0.012)$ per 100 people in mobile phone penetration is required to reverse the positive effect of FDI on the time required to build a warehouse while in Table 3 the corresponding threshold on the time required to start a business is $133.5(0.267 / 0.002)$ per 100 people in mobile phone penetration. The established thresholds at which ICT changes the effect of openness to reduce constraints to doing business make economic sense for the most part because they are within the ranges provided by summary statistics, notably: 0.000 to 147.202 for mobile phone penetration and 0.005 to 43.605 for Internet penetration.

In the light of the above, ICT can be enhanced to reach the computed ICT modifying policy thresholds by adopting policies designed to boost ICT penetration. Hence, it is relevant for policy makers to address issues associated with the absence of adequate infrastructure as well as concerns surrounding affordability of ICT which represents important barriers to ICT penetration. Schemes on universal coverage through low pricing and provision of ICT infrastructure are some steps in this direction. Hence, ICT can play the role of an interface between openness policies, business constraints and entrepreneurs (present and potential). Such interfaces can be facilitated if ICT policies are designed to enhance, inter alia: costeffectiveness, adoption, efficiency, access, reach and interactions.

\subsubsection{Theoretical contributions/implications}

Two main theoretical contributions of this study are connected to the literature, notably, complementary narratives on reducing information asymmetry and catch-up in the entrepreneurship indicators. First, with regard to the issue of information asymmetry, the net 
negative effects on doing business constraints is an indication that ICT reduces information asymmetry related to openness by providing timely information that facilitates the doing of business. Moreover, the inference also accords with the established evidence that ICT is negatively (positively) associated with the formal (informal) economic sector of economies in Africa (Asongu, 2013b), which further implies that entrepreneurial activities owing to increased globalisation are not exclusively limited to the formal economic sector and large companies. In a nutshell, openness-driven by ICT policies enable conditions that reduce informational rents that previously constrained the doing of business. In other words, the complementarity between ICT and openness improves business efficiency, which is broadly consistent with the theoretical underpinnings on financial allocation efficiency by means of information sharing in the banking industry (Claus \& Grimes, 2003). In the light of these analogies, the theoretical basis of information sharing in the financial industry can be extended to information asymmetry associated with increasing economic and financial openness.

Second, it is apparent from the findings that some doing business indicators are more stationary (or non-persistent or convergent) than others. For instance three main tendencies are apparent, namely: (i) consistently stationary (cost of business start-up procedure; number of procedures to enforce a contract; number of start-up procedures to enforce a contract; time required to build a warehouse and time required to register a property); (ii) consistently nonstationary (time required to prepare and pay taxes) and (iii) both stationary and non-stationary (time required to enforce a contract; time required to start a business; time to export and time to resolve an insolvency) business variables. From an economic interpretative standpoint, stationary (or evidence of convergence) implies that common policies on doing business can be adopted among countries because cross-country differences in the observed business variables are decreasing. The economic interpretation further indicates that theoretical underpinnings in the catch-up can be understood beyond income convergence (Asongu, 2014b). Such a theoretical insight is consistent with both studies on the neoclassical growth models (Solow, 1956; Swan, 1956; Baumol, 1986; Barro, 1991; Barro \& Sala-i-Martin, 1992, 1995; Mankiw et al., 1992; Fung, 2009) and other fields of economic development, notably: the knowledge economy (Asongu, 2017b); financial markets (Narayan et al., 2011; Bruno et al., 2012); negative government signals in the prediction of social unrests (Asongu \& Nwachukwu, 2016c) and inclusive human development (Mayer-Foulkes, 2010). 


\section{Conclusion and future research directions}

This study has examined how ICT influences openness to improve conditions of doing business in sub-Saharan Africa for the period 2000-2012. ICT is proxied with Internet and mobile phone penetration rates whereas openness is measured in terms of financial and trade globalisation. Ten doing business indicators are used. The empirical evidence is based on GMM with forward orthogonal deviations.

It is apparent from the findings that while there is substantial evidence that ICT complements openness to improve conditions for entrepreneurship, the effects are contingent on the dynamics of openness, ICT and entrepreneurship. Theoretical and practical policy implications have been discussed. Future research can improve extant literature by assessing how other policy variables can complement the ineluctable phenomenon of globalisation to improve entrepreneurship in SSA. Exploring good governance mechanisms should be a good step in this direction. Moreover, assessing how such interactions directly affect inclusive human development and unemployment are also worthwhile. 


\section{Appendices}

\section{Appendix 1: Definitions of variables}

\begin{tabular}{|c|c|c|c|}
\hline Variables & Signs & Definitions of variables (Measurements) & Sources \\
\hline $\begin{array}{l}\text { Cost of starting } \\
\text { business }\end{array}$ & Costostart & $\begin{array}{l}\text { Cost of business start-up procedures ( } \% \text { of GNI per } \\
\text { capita) }\end{array}$ & $\begin{array}{l}\text { World Bank } \\
\text { (WDI) }\end{array}$ \\
\hline $\begin{array}{l}\text { Contract } \\
\text { enforcement }\end{array}$ & Contractenf & Procedures to enforce a contract (number) & $\begin{array}{l}\text { World Bank } \\
\text { (WDI) }\end{array}$ \\
\hline $\begin{array}{l}\text { Start-up } \\
\text { procedure }\end{array}$ & Startupproced & Start-up procedures to register a business (number) & $\begin{array}{l}\text { World Bank } \\
\text { (WDI) }\end{array}$ \\
\hline Ware house time & Timewarehouse & Time required to build a warehouse (days) & $\begin{array}{l}\text { World Bank } \\
\text { (WDI) }\end{array}$ \\
\hline $\begin{array}{l}\text { Time to enforce a } \\
\text { contract }\end{array}$ & Timenforcontr & $\begin{array}{l}\text { Timenforcontr: Time required to enforce a contract } \\
\text { (days) }\end{array}$ & $\begin{array}{l}\text { World Bank } \\
\text { (WDI) }\end{array}$ \\
\hline $\begin{array}{l}\text { Time to register a } \\
\text { property }\end{array}$ & Timeregprop & Time required to register a property (days) & $\begin{array}{l}\text { World Bank } \\
\text { (WDI) }\end{array}$ \\
\hline $\begin{array}{l}\text { Time to start a } \\
\text { business }\end{array}$ & Timestartbus & Time required to start a business (days) & $\begin{array}{l}\text { World Bank } \\
\text { (WDI) }\end{array}$ \\
\hline Time to export & Timexport & Time to export (days) & $\begin{array}{l}\text { World Bank } \\
\text { (WDI) }\end{array}$ \\
\hline $\begin{array}{l}\text { Time to pay } \\
\text { taxes }\end{array}$ & Timetaxes & Time to prepare and pay taxes (hours) & $\begin{array}{l}\text { World Bank } \\
\text { (WDI) }\end{array}$ \\
\hline $\begin{array}{l}\text { Resolving an } \\
\text { insolvency }\end{array}$ & Timeresinsolv & Time to resolve insolvency (years) & $\begin{array}{l}\text { World Bank } \\
\text { (WDI) }\end{array}$ \\
\hline Trade Openness & Trade & Imports plus Exports of Commodities (\% of GDP) & $\begin{array}{l}\text { World Bank } \\
\text { (WDI) }\end{array}$ \\
\hline $\begin{array}{l}\text { Foreign } \\
\text { investment }\end{array}$ & FDI & Foreign Direct Investment inflows (\% of GDP) & $\begin{array}{c}\text { World Bank } \\
\text { (WDI) }\end{array}$ \\
\hline Mobile phones & Mobile & Mobile phone subscriptions (per 100 people) & $\begin{array}{l}\text { World Bank } \\
\text { (WDI) }\end{array}$ \\
\hline Internet & Internet & Internet penetration (per 100 people) & $\begin{array}{c}\text { World Bank } \\
\text { (WDI) }\end{array}$ \\
\hline GDP growth & GDPg & Gross Domestic Product (GDP) growth (annual \%) & $\begin{array}{c}\text { World Bank } \\
\text { (WDI) }\end{array}$ \\
\hline $\begin{array}{l}\text { Population } \\
\text { growth }\end{array}$ & Popg & Population growth rate (annual \%) & $\begin{array}{l}\text { World Bank } \\
\text { (WDI) }\end{array}$ \\
\hline Foreign aid & Aid & Total Development Assistance (\% of GDP) & $\begin{array}{c}\text { World Bank } \\
\text { (WDI) }\end{array}$ \\
\hline $\begin{array}{l}\text { Educational } \\
\text { Quality }\end{array}$ & Educ & Pupil teacher ratio in Primary Education & $\begin{array}{c}\text { World Bank } \\
\text { (WDI) }\end{array}$ \\
\hline
\end{tabular}

WDI: World Bank Development Indicators. 
Appendix 2: Summary statistics (2000-2012)

Cost of starting business

\begin{tabular}{llllc} 
Mean & SD & Minimum & Maximum & Observations \\
\hline 156.079 & 219.820 & 0.300 & 1540.2 & 445 \\
39.305 & 5.224 & 23.000 & 54.000 & 445 \\
9.856 & 3.005 & 3.000 & 18.000 & 445 \\
195.760 & 98.496 & 48.000 & 599 & 367 \\
683.024 & 277.839 & 230.000 & 1715 & 445 \\
82.592 & 74.197 & 9.000 & 389 & 412 \\
49.884 & 43.658 & 5.000 & 260 & 445 \\
33.789 & 14.344 & 10 & 78 & 375 \\
319.382 & 196.048 & 66 & 1120 & 375 \\
3.094 & 1.129 & 1.7 & 6.2 & 372 \\
23.379 & 28.004 & 0.000 & 147.202 & 572 \\
4.152 & 6.450 & 0.005 & 43.605 & 566 \\
78.177 & 36.138 & 20.964 & 209.87 & 597 \\
5.332 & 8.737 & -6.043 & 91.007 & 603 \\
4.714 & 6.322 & -47.552 & 63.379 & 608 \\
2.361 & 0.948 & -1.081 & 6.576 & 588 \\
43.601 & 14.529 & 12.466 & 100.236 & 444 \\
11.687 & 14.193 & -0.253 & 181.187 & 606
\end{tabular}

Contract enforcement

Start-up procedure

Ware house time

Time to enforce a contract

Time to register a property

Time to start a business

Time to export

Time to pay taxes

Resolving an insolvency

Mobile phone penetration

Internet penetration

Trade Openness

Foreign Direct Investment inflows

GDP growth

Population growth

Educational Quality

Foreign aid

S.D: Standard Deviation. 
Appendix 3: Correlation matrix

\begin{tabular}{|c|c|c|c|c|c|c|c|c|c|c|c|c|c|c|c|c|c|c|}
\hline $\begin{array}{l}\text { Cost- } \\
\text { ostart }\end{array}$ & $\begin{array}{l}\text { Contra- } \\
\text { ctenf }\end{array}$ & $\begin{array}{l}\text { Startup- } \\
\text { proced }\end{array}$ & $\begin{array}{l}\text { Timeware- } \\
\text { house }\end{array}$ & $\begin{array}{l}\text { Timen- } \\
\text { forcontr }\end{array}$ & $\begin{array}{l}\text { Time- } \\
\text { regprop }\end{array}$ & $\begin{array}{l}\text { Time- } \\
\text { startbus }\end{array}$ & $\begin{array}{l}\text { Time- } \\
\text { xport }\end{array}$ & $\begin{array}{l}\text { Time- } \\
\text { taxes }\end{array}$ & $\begin{array}{l}\text { Time- } \\
\text { resinsolv }\end{array}$ & Trade & FDI & GDPg & Popg & Educ & Aid & Mobile & Internet & \multirow[b]{2}{*}{ Costostart } \\
\hline \multirow{18}{*}{1.000} & 0.268 & 0.303 & 0.120 & -0.110 & 0.169 & -0.032 & 0.463 & 0.241 & 0.390 & -0.048 & -0.135 & 0.020 & 0.389 & 0.362 & 0.133 & -0.541 & -0.385 & \\
\hline & 1.000 & 0.180 & 0.025 & 0.080 & -0.040 & 0.028 & 0.216 & 0.345 & 0.276 & 0.036 & 0.149 & -0.022 & 0.144 & 0.094 & 0.049 & -0.324 & -0.093 & Contractenf \\
\hline & & 1.000 & -0.037 & -0.065 & -0.093 & 0.311 & 0.204 & 0.129 & 0.170 & 0.024 & -0.128 & 0.109 & 0.100 & 0.154 & -0.136 & -0.275 & -0.164 & Startupproced \\
\hline & & & 1.000 & 0.150 & 0.221 & 0.094 & 0.012 & -0.022 & 0.087 & 0.119 & -0.059 & -0.113 & -0.093 & -0.003 & 0.125 & 0.086 & -0.121 & Timewarehouse \\
\hline & & & & 1.000 & -0.213 & 0.344 & -0.197 & -0.060 & 0.048 & 0.172 & 0.184 & -0.034 & -0.212 & -0.285 & 0.209 & 0.047 & 0.098 & Timenforcontr \\
\hline & & & & & 1.000 & -0.129 & -0.054 & -0.009 & -0.015 & -0.067 & -0.179 & 0.004 & 0.039 & 0.087 & 0.040 & -0.193 & -0.056 & Timeregprop \\
\hline & & & & & & 1.000 & -0.011 & 0.158 & 0.165 & 0.265 & 0.236 & -0.049 & -0.263 & -0.149 & -0.093 & 0.043 & 0.046 & Timestartbus \\
\hline & & & & & & & 1.000 & 0.212 & 0.386 & -0.146 & -0.063 & 0.181 & 0.327 & 0.589 & 0.031 & -0.554 & -0.476 & Timexport \\
\hline & & & & & & & & 1.000 & 0.167 & 0.010 & 0.027 & -0.090 & 0.103 & 0.187 & -0.164 & -0.141 & -0.161 & Timetaxes \\
\hline & & & & & & & & & 1.000 & -0.215 & -0.026 & -0.004 & 0.316 & 0.408 & 0.221 & -0.435 & -0.261 & Timeresinsolv \\
\hline & & & & & & & & & & 1.000 & 0.338 & 0.093 & -0.325 & -0.348 & -0.061 & 0.243 & 0.182 & Trade \\
\hline & & & & & & & & & & & 1.000 & 0.065 & 0.116 & -0.135 & 0.342 & 0.063 & 0.067 & FDI \\
\hline & & & & & & & & & & & & 1.000 & 0.252 & 0.213 & 0.260 & -0.247 & -0.049 & GDPg \\
\hline & & & & & & & & & & & & & 1.000 & 0.360 & 0.497 & -0.458 & -0.431 & Popg \\
\hline & & & & & & & & & & & & & & 1.000 & 0.120 & -0.571 & -0.526 & Educ \\
\hline & & & & & & & & & & & & & & & 1.000 & -0.259 & -0.207 & \\
\hline & & & & & & & & & & & & & & & & 1.000 & 0.661 & Mobile \\
\hline & & & & & & & & & & & & & & & & & 1.000 & Internet \\
\hline
\end{tabular}

Costostart: cost of business start-up procedure. Contractenf: Procedure to enforce a contract. Startupproced: Start-up procedures to register a business. Timewarehouse: Time required to build a warehouse.

Timenforcontr : Time required to enforce a contract. Timeregroup: Time required to register a property. Timestartbus : Time required to start a business. Timexport: Time to export. Timetaxes: Time to prepare and pay taxes. Timeresinsolv : Time to resolve insolvency. Educ: Quality of primary education. GDPg: GDP growth. Popg: Population growth. FDI: Foreign Direct Investment inflows. Aid: Foreign aid. Mobile: Mobile Phone penetration. 


\section{Appendix 4: Persistence in doing business variables}

\begin{tabular}{|c|c|c|c|c|c|c|c|c|c|c|}
\hline & $\begin{array}{l}\text { Cost- } \\
\text { ostart }\end{array}$ & $\begin{array}{l}\text { Contra- } \\
\text { ctenf }\end{array}$ & $\begin{array}{l}\text { Startup- } \\
\text { proced }\end{array}$ & $\begin{array}{l}\text { Timeware- } \\
\text { house }\end{array}$ & $\begin{array}{l}\text { Timen- } \\
\text { forcontr }\end{array}$ & $\begin{array}{l}\text { Time- } \\
\text { regprop }\end{array}$ & $\begin{array}{l}\text { Time- } \\
\text { startbus }\end{array}$ & $\begin{array}{l}\text { Time- } \\
\text { xport }\end{array}$ & $\begin{array}{l}\text { Time- } \\
\text { taxes }\end{array}$ & $\begin{array}{l}\text { Time- } \\
\text { resinsolv }\end{array}$ \\
\hline Costostart (-1) & 0.9284 & & & & & & & & & \\
\hline Contractenf (-1) & & 0.9970 & & & & & & & & \\
\hline Startupproced (-1) & & & 0.9400 & & & & & & & \\
\hline Timewarehouse (-1) & & & & 0.9640 & & & & & & \\
\hline Timenforcontr $(-1)$ & & & & & 0.9883 & & & & & \\
\hline Timeregprop (-1) & & & & & & 0.9187 & & & & \\
\hline Timestartbus (-1) & & & & & & & 0.9263 & & & \\
\hline Timexport (-1) & & & & & & & & 0.9767 & & \\
\hline Timetaxes (-1) & & & & & & & & & 0.9923 & \\
\hline Timeresinsolv (-1) & & & & & & & & & & 0.9997 \\
\hline
\end{tabular}

Costostart: cost of business start-up procedure. Costostart (-1): lagged cost of business start-up procedure. Contractenf: Procedure to enforce a contract. Startupproced: Start-up procedures to register a business. Timewarehouse: Time required to build a warehouse. Timenforcontr : Time required to enforce a contract. Timeregroup: Time required to register a property. Timestartbus : Time required to start a business. Timexport: Time to export. Timetaxes: Time to prepare and pay taxes. Timeresinsolv : Time to resolve insolvency.

\section{References}

African Economic Research Consortium (AERC, 2014). "Youth Employment: Opportunities and Challenges", $40^{\text {th }}$ Plenary Session of the AERC's Biannual Research Workshop, Lusaka, Zambia (November, $30^{\text {th }}$ ).

http://aercafrica.org/index.php/news-events/212-aerc-biannual-workshop-climate-change-andeconomic-development-2 (Accessed: 06/01/2015).

Allen, T. J., Gloor, P. A., Colladon, A. F., Woerner, S. L., \& Raz, O., (2016). "The power of reciprocal knowledge sharing relationships for startup success", Journal of Small Business and Enterprise Development, 23(3), pp. 636-651.

Amavilah, A., Asongu, S. A., \& Andrés, A. R., (2017). "Effects of globalization on peace and stability: Implications for governance and the knowledge economy of African countries", Technology Forecasting and Social Change, 122(September), pp. 91-103.

Anyanwu, J. C., (2012). "Developing Knowledge for the Economic Advancement of Africa", International Journal of Academic Research in Economics and Management Sciences, 1(2), pp. 73-111.

Arellano, M., \& Bond, S., (1991), "Some tests of specification for panel data: Monte Carlo evidence and an application to employment equations" The Review of Economic Studies, 58(2), pp. 277-297.

Arellano, M., \& Bover, O., (1995), "Another look at the instrumental variable estimation of error components models", Journal of Econometrics, 68(1), pp. 29-52.

Aricat, R. G., (2015). "Is (the study of) mobile phones old wine in a new bottle? A polemic on communication-based acculturation research", Information Technology \& People, 28(4), pp.806-824. 
Asiedu, E., (2014). "Does Foreign Aid in Education Promote Economic Growth? Evidence From Sub-Saharan Africa”, Journal of African Development, 16(1), pp. 37-59.

Asongu, S. A., (2013a). "How Would Population Growth Affect Investment in the Future? Asymmetric Panel Causality Evidence for Africa", African Development Review, 25, (1), pp. 14-29.

Asongu, S. A., (2013b). "How has mobile phone penetration stimulated financial development in Africa", Journal of African Business, 14(1), pp. 7-18.

Asongu, S. A., (2014a). "Globalization, (fighting) corruption and development: how are these phenomena linearly and nonlinearly related in wealth effect?, Journal of Economic Studies, 41(3), pp. 346-369.

Asongu, S. A., (2014b). "African development: beyond income convergence", South African Journal of Economics, 83(3), pp. 334-353.

Asongu, S. A., (2015). "Long-term effects of population growth on aggregate investment dynamics: Selected country evidence for Africa", African Journal of Economic and Management Studies, 6(3), pp. 225-250.

Asongu, S. A., (2017a). "Conditional Determinants of Mobile Phones Penetration and Mobile Banking in Sub-Saharan Africa", Journal of the Knowledge Economy.

DOI: $10.1007 \% 2 F s 13132-015-0322-z$.

Asongu, S. A., (2017b). "Knowledge Economy Gaps, Policy Syndromes and Catch-Up Strategies: Fresh South Korean Lessons to Africa", Journal of the Knowledge Economy, 8(1), pp. 211-253.

Asongu, S. A., Amavilah, V., \& Andrés, A. R., (2014). "Economic Implications of Business Dynamics for KE-Associated Economic Growth and Inclusive Development in African Countries", African Governance and Development Institute Working Paper No. 14/023, Yaoundé.

Asongu, S. A., \& De Moor, L., (2017). "Financial Globalisation Dynamic Thresholds for Financial Development: Evidence from Africa", The European Journal of Development Research, 29(1), pp. 192-212.

Asongu, S. A., \& Le Roux, S., (2017). "Enhancing ICT for inclusive human development in Sub-Saharan Africa", Technological Forecasting and Social Change, 118(May), pp. 44-54.

Asongu, S. A., \& Nwachukwu, J. C., (2016a). "The Role of Governance in Mobile Phones for Inclusive Human Development in Sub-Saharan Africa", Technovation, 55-56(SeptemberOctober), pp. 1-13.

Asongu, S. A, \& Nwachukwu, J. C., (2016b). "The Mobile Phone in the Diffusion of Knowledge for Institutional Quality in Sub Saharan Africa", World Development, 86(October), pp. 133-147. 
Asongu, S. A., \& Nwachukwu, J., (2016c). "Revolution empirics: predicting the Arab Spring”, Empirical Economics, 51(2), pp. 439-482.

Asongu, S. A., \& Biekpe, N., (2017). "Mobile Phone Innovation and Entrepreneurship in Sub-Saharan Africa", African Governance and Development Institute Working Paper No. 17/023, Yaoundé.

Asongu, S. A, Nwachukwu, J. C., \& Orim, S-M., (2016). "Mobile phones, Institutional Quality and Entrepreneurship in Sub Saharan Africa", African Governance and Development Institute Working Paper, Yaoundé.

Baltagi, B. H., (2008). "Forecasting with panel data", Journal of Forecasting, 27(2), pp. 153173.

Barro, R., (1991). "Economic Growth in a Cross Section of Countries". Quarterly Journal of Economics 196 (2/May), pp. 407-443.

Barro, R. J., \& Sala-i-Martin, X., (1992). “Convergence”, Journal of Political Economy, 100(2), pp. 223-251.

Barro, R. J., \& Sala-i-Martin, X., (1995). Economic Growth. The MIT Press, Cambridge, MA.

Baumol, W. J., (1986). "Productivity, growth, convergence and welfare: what the long run data show", American Economic Review, 76(5), pp. 1072-1085.

Bond, S., Hoeffler, A., \& Tample, J. (2001) "GMM Estimation of Empirical Growth Models", University of Oxford.

Blundell, R., \& Bond, S., (1998). "Initial conditions and moment restrictions in dynamic panel data models" Journal of Econometrics, 87(1), pp. 115-143.

Brambor, T., Clark, W. M., \& Golder, M., (2006). "Understanding Interaction Models:Improving Empirical Analyses”, Political Analysis, 14(1), pp. 63-82.

Brixiova Z., Ncube, M. \& Bicaba, Z., (2015). "Skills and Youth Entrepreneurship in Africa: Analysis with Evidence from Swaziland”, World Development, 67(3), pp.11-26.

Bruno, G., De Bonis, R., \& Silvestrini, A., (2012). "Do financial systems converge? New evidence from financial assets in OECD countries". Journal of Comparative Economics; 40(1), pp. 141-155.

Byrne, E., Nicholson, B., \& Salem, F., (2011). "Information communication technologies and the millennium development goals", Information Technology for Development, 17(1), pp. 1-3.

Carmody, P., (2013). "A knowledge economy or an information society in Africa? Thintegration and the mobile phone revolution", Information Technology for Development, 19(1), pp. 24-39. 
Chavula, H. K., (2013). "Telecommunications development and economic growth in Africa", Information Technology for Development, 19(1), pp. 5-23.

Claus, I., \& Grimes, A., (2003). "Asymmetric Information, Financial Intermediation and the Monetary Transmission Mechanism: A Critical Review", NZ Treasury Working Paper No. 13/019, Wellington.

Dewan, S., \& Ramaprasad, J., (2014). "Social media, traditional media and music sales", MIS Quarterly, 38(1), pp. 101-128.

Devarajan, S, Easterly, W., \& Pack, H., (2001). "Is investment in Africa too high or too low? Macro- and micro-evidence”, Journal of African Economies, 10 (suppl 2), pp. 81-108.

Eifert, B, Gelb, A, \& Ramachandran, V., (2005). "Business Environment and Comparative Advantage in Africa: Evidence from the Investment Climate Data". Working Paper No. 56, Center for Global Development, Washington, DC.

Eifert, B., Gelb, A., \& Ramachandran, V., (2008). "The Cost of Doing Business in Africa: Evidence from Enterprise Survey Data”, World Development, 36(9), pp. 1531-1546.

Esselaar, B., Gilwald, A., \& Stork, C., (2007). "Towards an Africa e-index: Telecommunications sector performance in 16 African countries". Research ICT Africa, $\underline{\text { www.researchICTafrica.net }}$

Fafchamps, M., (2001). "Networks, communities and markets in Sub-Saharan Africa: Implications for firm growth and investment", Journal of African Economies, 10 (supl 2), pp. 109-142.

Fung, M. K., (2009). "Financial development and economic growth: convergence or divergence?”. Journal of International Money and Finance, 28(1), pp. 56-67.

Gerba, D. T. (2012). "Impact of entrepreneurship education on entrepreneurial intentions of business and engineering students in Ethiopia", African Journal of Economic and Management Studies, 3(2), pp. 258-277.

Gille, L., Noumba Um, P, Rudel, C., \& Simon, L., (eds) (2002) “A model for calculating interconnection costs in telecommunications". The World Bank. http://www.ppiaf.org/sites/ppiaf.org/files/publication/WB\%20$\% 20$ Model\%20Calculating\%20Interconnection\%20Costs\%20Telecoms\%202004.pdf (Accessed: 27/11/2014).

Gilwald, A., \& Stork, C., (2008). "Towards evidence-based ICT policy and regulation: ICT access and usage in Africa", Volume 1 policy Paper Two, Research ICT Africa, www.researchICTafrica.net .

Gripenberg, P., (2011). "Computer self-efficacy in the information society: Design of learning strategies, mechanisms and skill areas", Information Technology \& People, 24(3), pp.303 331. 
Gutierrez, L. H., Lee, S., \& Virto, L. R., (2009). "Market concentration and performance in mobile markets in Africa and Latin America". OECD Development Center (mimeo).

Gunning, J. W., \& Mengistae, T., (2001). "Determinants of African manufacturing investment: The microeconomic evidence", Journal of African Economies, 10 (suppl 2), pp. 48-80.

Hossain, M. A., \& Quaddus, M., (2011). "The adoption and continued usage intention of RFID: an integrated framework", Information Technology \& People, 24(3), pp.236-256.

Ita, J. J., Singh P., \& Adelosa, S., (2014). "Factor that Influence Entrepreneurial Intentions Among Undergraduates of South-South and Southeast Nigeria", Oxford Brookes University. http://dx.doi.org/10.2139/ssrn.2506268 (Accessed: 08/12/2014).

Johri, A., \& Nair, S., (2011). "The role of design values in information system development for human benefit", Information Technology \& People, 24(3), pp.281-302.

Jones, N., Borgman, R., Ulusoy, E., (2015). "Impact of social media on small businesses", Journal of Small Business and Enterprise Development, 22(4), pp.611-632.

Kamel, S., (2005). "The use of information technology to transform the banking sector in developing nations", Information Technology for Development, 11(4), pp. 305-312.

Kautz, K., (2011). "Investigating the design process: participatory design in agile software development", Information Technology \& People, 24(3), pp.217-235.

Kivuneki, F. N., Ekenberg, L., Danielson, M., \& Tusubira. F.F., (2011). "Perceptions of the role of ICT on quality of life in rural communities in Uganda", Information Technology for Development, 21(1), pp. 61-80.

Khavul, S., Bruton, J. D., \& Wood, E., (2009). "Informal Family Business in Africa", Entrepreneurship: Theory \& Practice, 33(6), pp. 1219-1238.

Kreps, D., \& Kimppa, K., (2015). "Theorising Web 3.0: ICTs in a changing society", Information Technology \& People, 28(4), pp.726 - 741.

Kuada, J., (2009). "Gender, Social Networks, and Entrepreneurship in Ghana", Journal of African Business, 10(1), pp. 85-103.

Kuada, J., (2015). Private Enterprise-Led Economic Development in Sub-Saharan Africa The Human Side of Growth First edition by Kuada, J, Palgrave Macmillan: New York.

Lahtiranta, J., Koskinen, J. S. S., Knaapi-Junnila, S., \& Nurminen, M., (2015). "Sensemaking in the personal health space", Information Technology \& People, 28(4), pp.790-805.

Lennerfors, T. T., Fors, P., \& van Rooijen, J., (2015). "ICT and environmental sustainability in a changing society: The view of ecological World Systems Theory", Information Technology \& People, 28 (4), pp.758-774. 
Levendis, J., \& Lee, S. H., (2013). "On the endogeneity of telecommunications and economic growth: evidence from Asia”, Information Technology for Development, 19(1), pp. $62-85$.

Love, I., \& Zicchino, L., (2006). "Financial Development and Dynamic Investment Behaviour: Evidence from Panel VAR" .The Quarterly Review of Economics and Finance, 46(2), pp. 190-210.

Mankiw, N. G., Romer, D., \& Weil, D. N., (1992). "A contribution to the empirics of economic growth”, Quarterly Journal of Economics, 107(May), pp. 407-437.

Mayer-Foulkes, D., (2010). "Divergences and Convergences in Human Development". UNDP Human Development Research Paper 2010/20, Paris.

McCann, M., \& Barlow, A., (2015). "Use and measurement of social media for SMEs", Journal of Small Business and Enterprise Development, 22(2), pp. 273-287.

Mensah, S. N., \& Benedict, E., (2010). "Entrepreneurship training and poverty alleviation: Empowering the poor in the Eastern Free State of South Africa", African Journal of Economic and Management Studies, 1(2), pp. 138-163.

Mpogole, H., Usanga, H., \& Tedre, M., (2008). "Mobile phones and poverty alleviation: a survey study in rural Tanzania", Proceedings of M4D 2008, Karlstad University, Sweden, pp. $62-72$

Murphy, J., \& Carmody, P. (2015). Africa's Information Revolution: Technical Regimes and Production Networks in South Africa and Tanzania. Oxford: Wiley-Blackwell.

Narayan, P. K., Mishra, S., \& Narayan, S., (2011). "Do market capitalization and stocks traded converge? New global evidence", Journal of Banking and Finance, 35(10), pp. 27712781.

N'da, K.C., (2012). "The cost of doing business in Sub-Saharan Africa Bridges Africa", International Center for Trade and Sustainable Development, 1(6): http://www.ictsd.org/bridges-news/bridges-africa/news/the-cost-of-doing-business-insubsaharan-africa (Accessed: 15/08/2014).

Neven, D., \& Droge, C, L. M., (2001). “A diamond for the poor? Assessing Porter's diamond model for the analysis of agro-food clusters in developing countries". http://www.agrifood.info/Agrifood/members/Congress/Congress2001Papers/Symposium/Nev en.pdf (Accessed: 15/08/2014).

Oluwatobi, S., Efobi, U.R., Olurinola, O.I., Alege, P. (2015), "Innovation in Africa: Why Institutions Matter", South African Journal of Economics, 83(3), pp. 390-410.

Oseifuah, E. K., (2010). "Financial literacy and youth entrepreurship in South Africa", African Journal of Economic and Management Studies, 1(2), pp. 164-182.

Patrignani, N, \& Whitehouse, D., (2015). "Slow tech: bridging computer ethics and business ethics”, Information Technology \& People, 28(4), pp.775-789. 
Paul, B., Bhorat, H., \& Cheadle, H., (2010). "The cost of "doing business and labour regulation: The case of South Africa”, International Labour Review, 149(1), pp. 73-91.

Penard, T., Poussing, N., Yebe, G. Z., \& Ella, P. N., (2012). "Comparing the Determinants of Internet and Cell Phone Use in Africa: Evidence from Gabon ", Communications \& Strategies, 86 (Second Quarter), pp. 65-83.

Petrakis, P. E., \& Stamatakis, D. (2002). "Growth and educational levels: a comparative analysis". Economics of Education Review, 21 (2), pp. 513-521.

Ponelis, S. R., \& Holmner, M. A., ( 2013a). "ICT in Africa: Enabling a Better Life for All”, Information Technology for Development, 21(1), pp. 1-11.

Ponelis, S. R., \& Holmner, M. A., ( 2013b). "ICT in Africa: Enabling a Better Life for All”, Information Technology for Development, 21(1), pp. 163-177.

Porter, M. E., (1990). The Competitive Advantage of Nations. New York: Free Press.

Porter, M. E., (1998). "The Adam Smith Address: Location, Clusters, and the "New" Microeconomics of Competition". Business Economics, 33(1), pp. 7-13. http://www.econ.nyu.edu/dept/courses/niemira/980107.pdf (Accessed: 8/11/2014).

Qureshi, S., Kamal, M., \& Keen, P. (2009). Knowledge networking to overcome the digital divide. In Knowledge management and organizational learning (pp. 215-234). Springer US.

Qureshi, S., (2013a). "What is the role of mobile phones in bringing about growth?", Information Technology for Development, 19(1), pp. 1-4.

Qureshi, S., (2013b). "Networks of change, shifting power from institutions to people: how are innovations in the use of information and communication technology transforming development?", Information Technology for Development, 19(2), pp. 97-99.

Qureshi, S., (2013c). "Information and Communication Technologies in the Midst of Global Change: How do we Know When Development Takes Place?", Information Technology for Development, 19(3), pp. 189-192.

Richardson, H. W., (1969). Regional Economics: Location Theory, Urban Structure, and Regional Change. New York: Praeger Publishers. Chapters 1-5.

Roodman, D., (2009a). "A Note on the Theme of Too Many Instruments", Oxford Bulletin of Economics and Statistics, 71(1), pp. 135-158.

Roodman, D., (2009b). "How to do xtabond2: An introduction to difference and system GMM in Stata”, Stata Journal, 9(1), pp. 86-136.

Roztocki, N., \& Weistroffer, H. R. (2016). "Conceptualizing and Researching the Adoption of ICT and the Impact on Socioeconomic Development", Information Technology for Development, 22(4), 541-549. 
Singh, S., Simpson, R., Mordi, C., \& Okafor, C., (2011). "Motivation to become an entrepreneur : a study of Nigerian women's decisions", African Journal of Economic and Management Studies, 2(2), pp. 202-219.

Smith, A., (1937)[1776] An Inquiry into the Nature and causes of the Wealth of Nations. Edwin Canna (ed) and Max Lerner (introducer). New York: modern Library. Book 1, Chapters 1-3.

Solow, R. M., (1956). "A contribution to the theory of economic growth", Quarterly Journal of Economics, 70(1), pp. 65-94.

Stan, E., \& Garnsey, E., (2006). Entrepreneurship and the Knowledge Economy, University of Cambridge.

Spring, A., Rolfe, R., \& Odera, L., (2013). "Sub-Saharan Africa Business Environment Report: 2012-13 - Business Information at a Ready Glance". http://warrington.ufl.edu/centers/ciber/docs/SABER_2012-2013.pdf (Accessed 8/15/2014).

Stigler, G. J., (1957). Adam Smith: Selections from the 'The Wealth of nations'. New York: Wiley Blackwell.

Swan, T., (1956). "Economic growth and capital accumulation". Economic Record, 32(2), pp. 334-361.

Taplin, R., \& Snyman, M., (2004). "Doing business in South Africa's new mining environment: A legal perspective”, CIM Bulletin, 97(1078), pp. 91-98.

Tapsoba, S. J-A., (2010). "Trade Intensity and Business Cycle Synchronicity in Africa", African Development Review, 22(1), pp. 149-172.

Tatnall , A., (2015). "Computer education and societal change: History of early courses in computing in universities and schools in Victoria", Information Technology \& People, 28(4), pp. $742-757$.

Tchamyou, V. S., (2016). "The role of knowledge economy in African business", Journal of the Knowledge Economy. DOI: 10.1007/s13132-016-0417-1.

Venable, J. R., Pries-Heje, J., Bunker, D., Russo, N. L., (2011). "Design and diffusion of systems for human benefit: Toward more humanistic realisation of information systems in society", Information Technology \& People, 24(3), pp.208-216.

Wang, Y., (2016). "Investigating dynamic capabilities of family businesses in China: a social capital perspective", Journal of Small Business and Enterprise Development, 23(4), pp. 10571080.

Watts, S., \& Wyner, G., (2011). "Designing and theorizing the adoption of mobile technology-mediated ethical consumption tools", Information Technology \& People, 24(3), pp. 257-280. 
World Bank (2013). "Doing Business in the East African Community 2013", The World Bank Group, http://www.doingbusiness.org/ /media/WBG/DoingBusiness/Documents/SpecialReports/DB13-EAC.pdf (Accessed: 03/11/2016). 